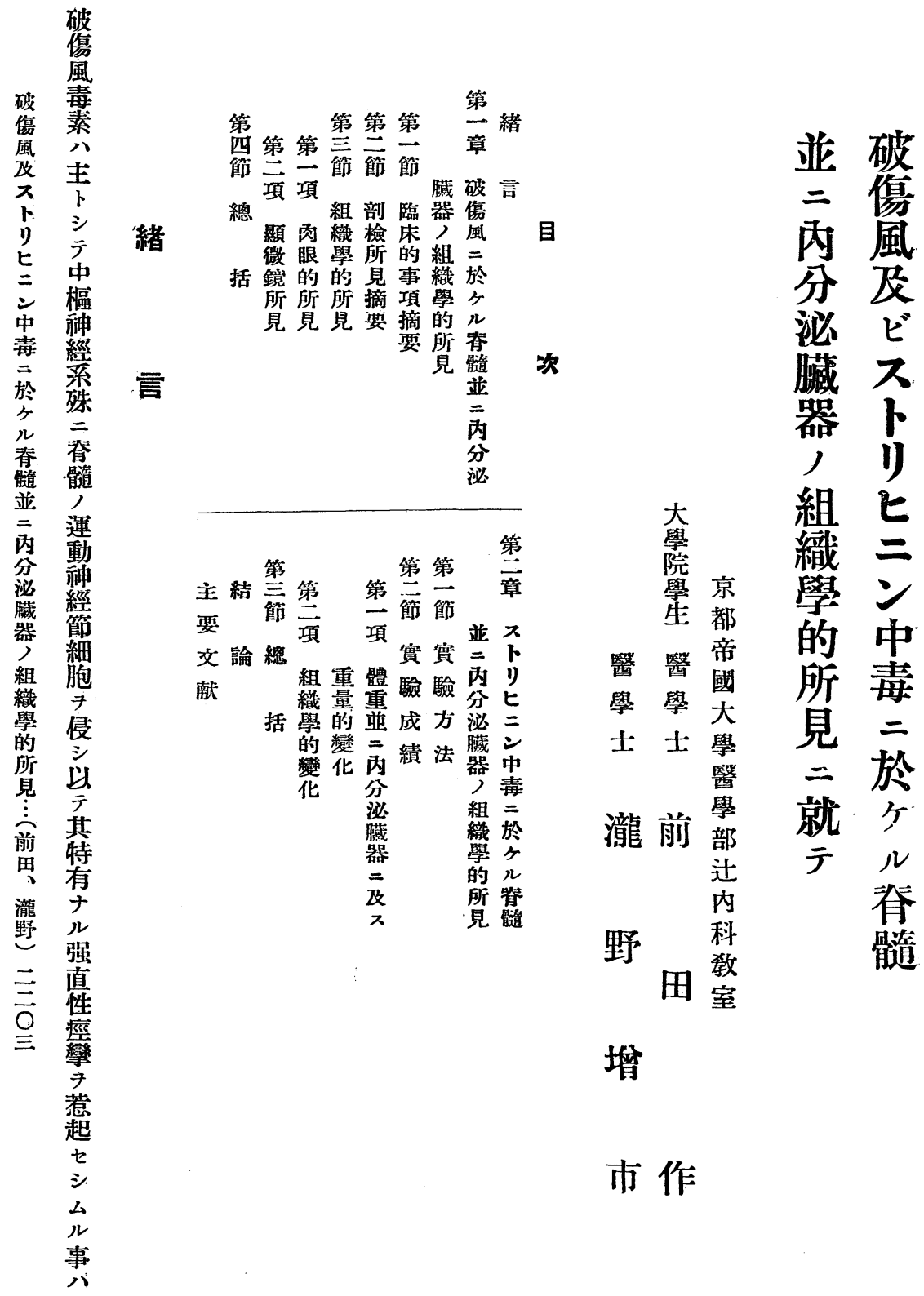




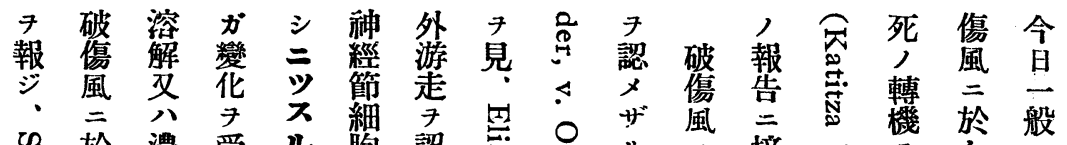

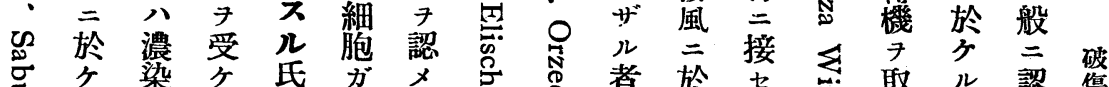

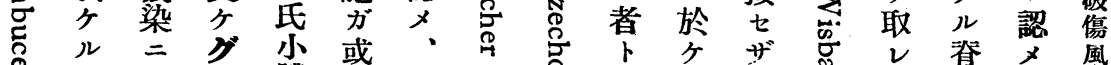

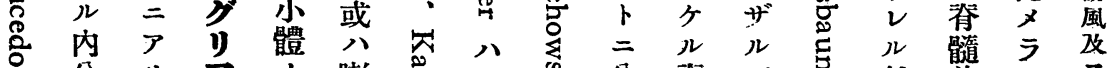

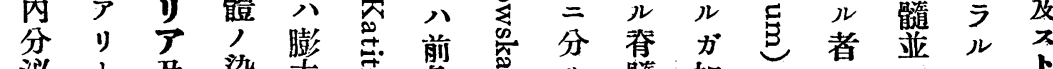

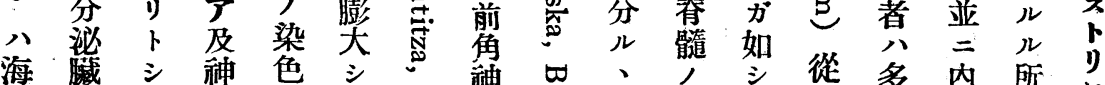

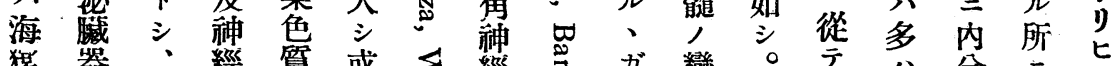

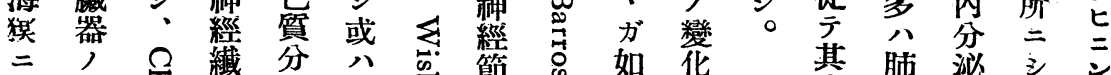

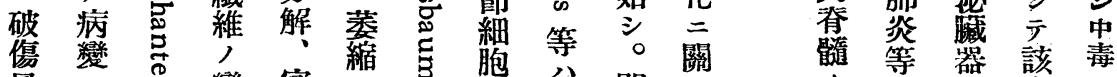

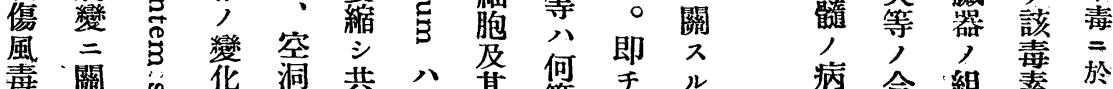

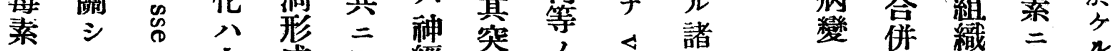

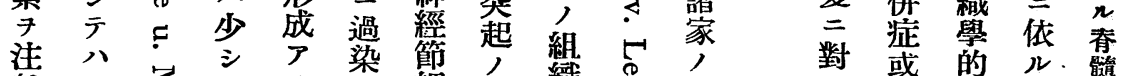

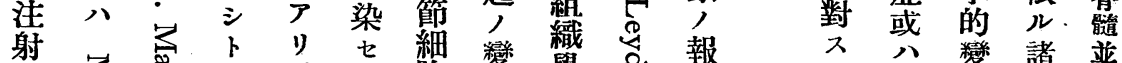

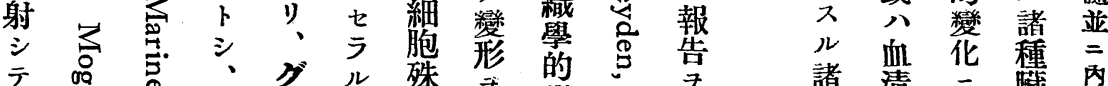

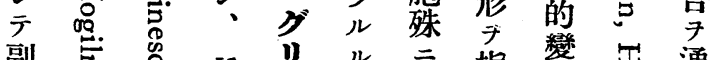

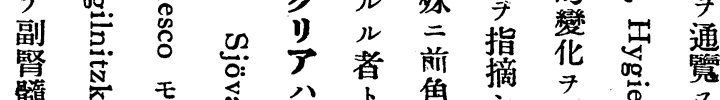

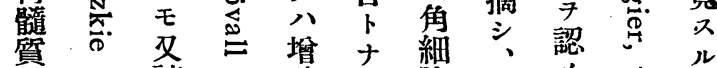

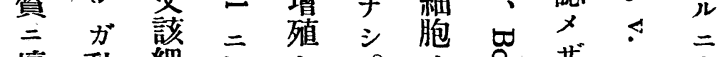

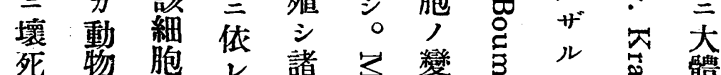

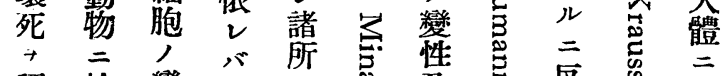

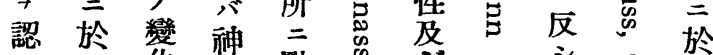

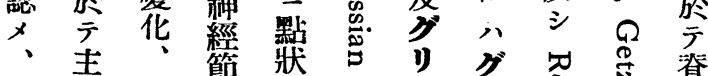

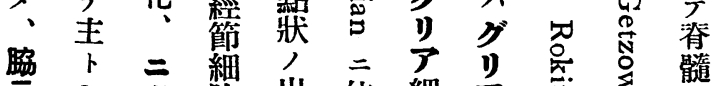

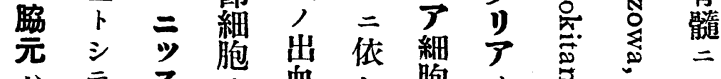

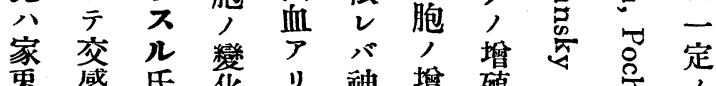

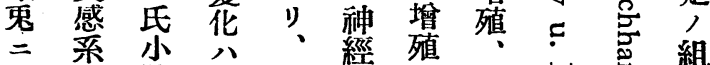
於三體主

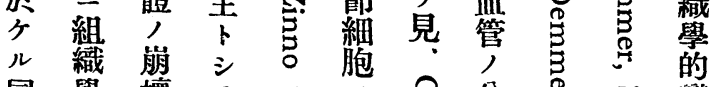

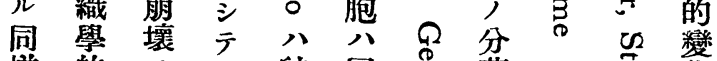

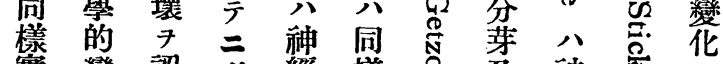

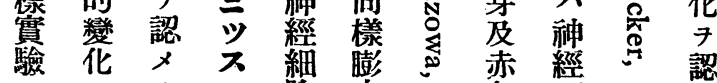

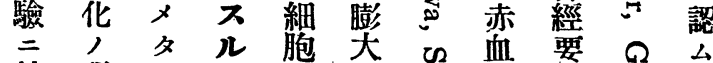

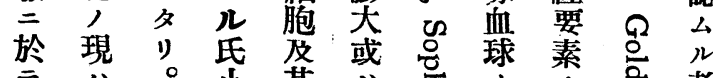

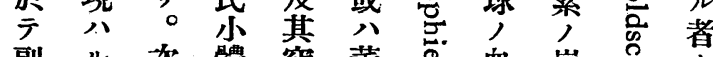

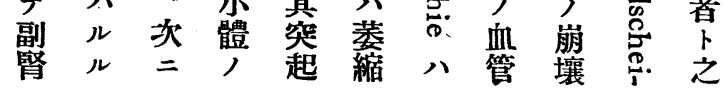

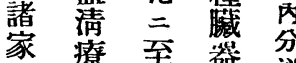

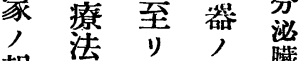

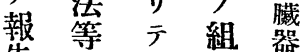
告足織器, 来影向學組 冬響研的緇

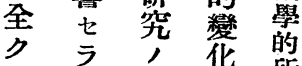

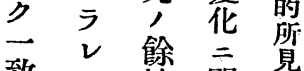

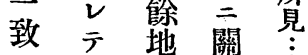

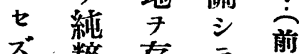
爻慗存盆腮

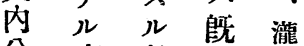
分病者暨灌 沁像音多 留 如 數

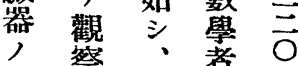
戀繁荎著 花公筑研 三事破究 至甚智了 》)分風》 亏 困患 八䧼著踓 未陑望 多艺产破 


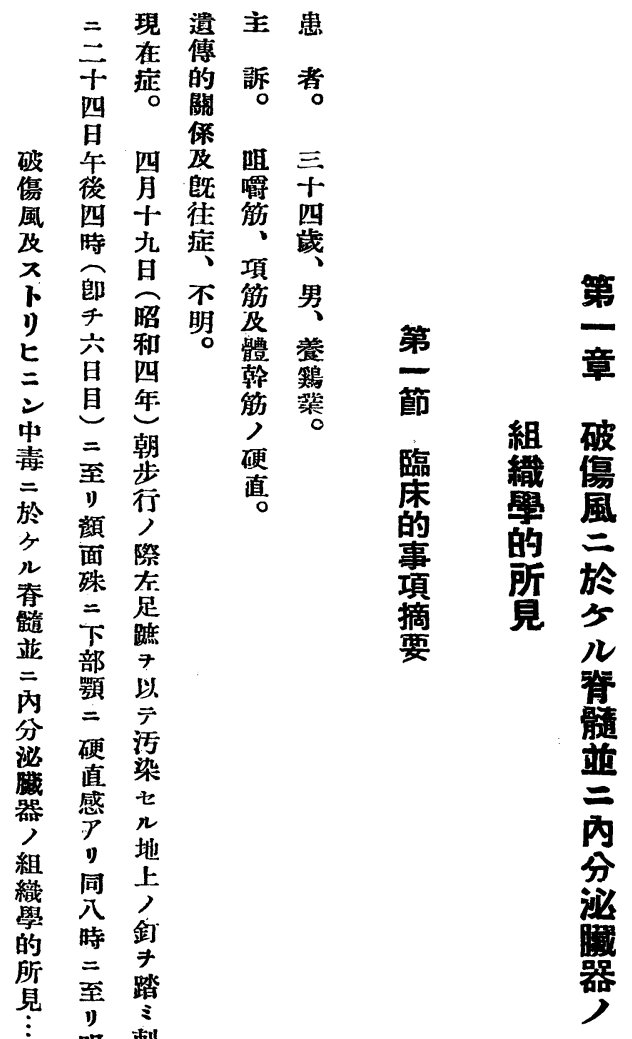

之風卢床ナ的著

報 類 济觀 材, 變 告 悠之察料如 無

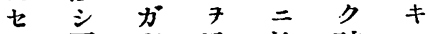

二屡春逐依破・7

卜先簿分り傷報

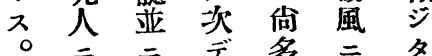

依内同, 於》

》分患檢 占

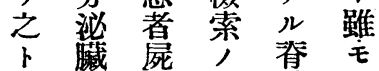

對器 $尹$ 要髓未

比, 比亚分

七 組 較 ル二諸

亏織的者內種

$\checkmark$ 學 速 r 分 内

夕的三云泌分

ル 檢 解 7 藏 泌

實索 剖べ器 惐

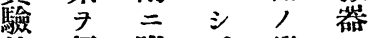

的行附。變三

ス

下 夕全等

リルク就之

七ョ他最テ无

二边近八采

ン 合當末統

、荮併害各的

テ 三 症 學 完 觀

夕其 無 过全 祭

ヌ結キ内ナ

ス 果 7 科 嫁

二 確 二說 ゲ

就 報 女 於明 夕

テ告タテ

同七ル破達者

樣 シ 7 傷 七 哭

人上風ザキ

檢 ス 患

絮 ル比者 ガ如

行者較光如辛。

七 好 例 7

シ 適 二 D

テ侣 遭テ

以余儿遇可

等 材 的成

併 八 料之的

テ破さ婎り適 


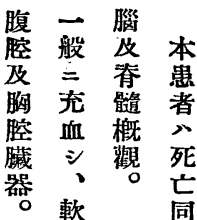
腦 硬 日

等膜腦 午

肝制〉元

呺離鹳 時

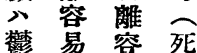

血易 後

>腦 = 約

外呬 $三+$

藷轉、宁諸

變腦䈏 間

ナ底分後

ク部 小

脾 三許 剖

獩蓄炒檢

買變 暗 ス

常厅赤 ル

ナ・ク色 三

胃ル流主

腸 ビ 血 ル

八 1 所

充 氏 容見

血滆 $v$ 次

强墨硬腦

》䔬腦 如

副子笑。

督著

延 變

形骨避

大 脜 見

サ 橋 :

尋 其 軟

常 他 脕

$=$ 答 膜

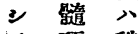

テ硬 稍

割 膜 々

面 外 混

兩面 濁

質 曋 觀

境 常

界 $\neq$ 》

分 認 、

明 $x$ 細

= ズ 血

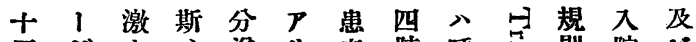
五ぶナつ透り者肢时志則院ビ

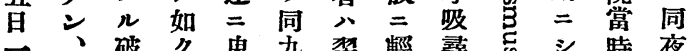

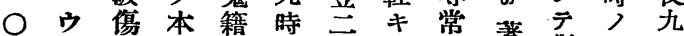
c.c. 口風患 $==\cdot$ 干硬 $=$ 者傷症時破 しビノ者入至五直シ明口候當傷 スり

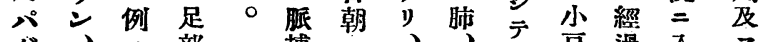

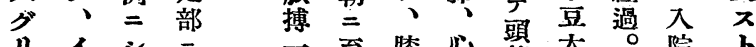

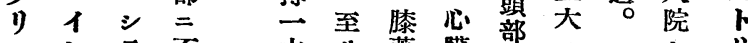

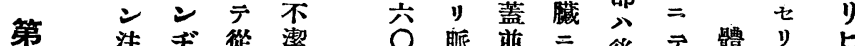

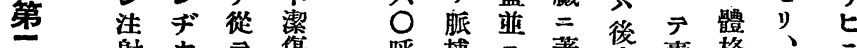

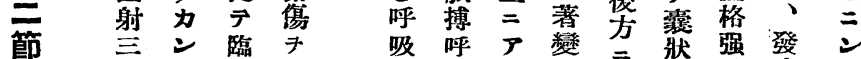

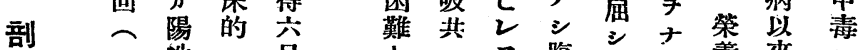
見 $\overrightarrow{0}$ 性 $=$ 日 $\quad$ 学

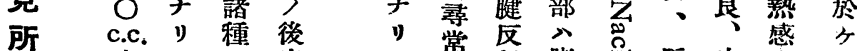
見宛 $ン>$ 定常射膨突、脈皮学么

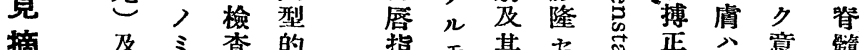
要 $三=き ナ$ 端卡他 ゙

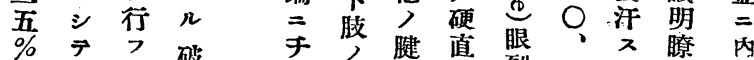
葡他能破厂硬压=裂额刺分

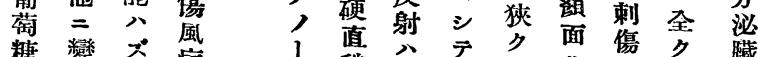

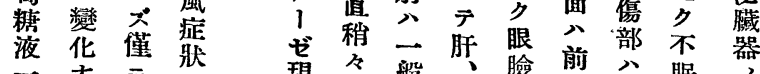
$\overrightarrow{0}$ ナ

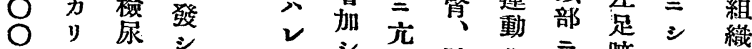

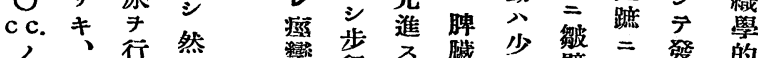

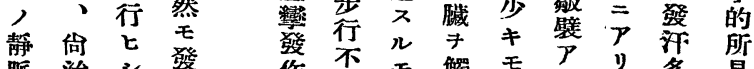

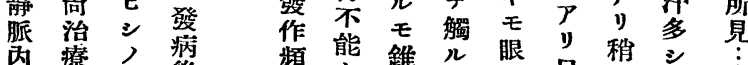

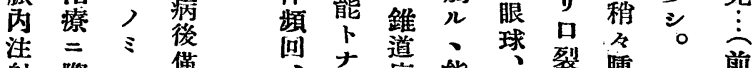

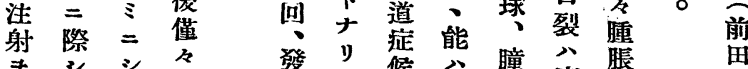
艾 シ シ 令 發

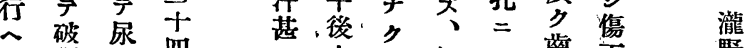
夕傷 八四時六知軀 齿面野 リ風比時

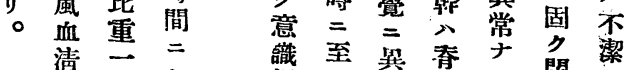

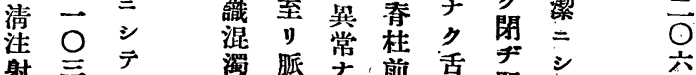
射三死 濁 脈 テ 前 舌即 $゙$ 回

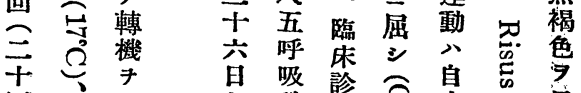
四、取午稍斷合息的是

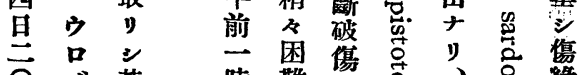

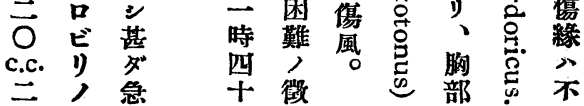




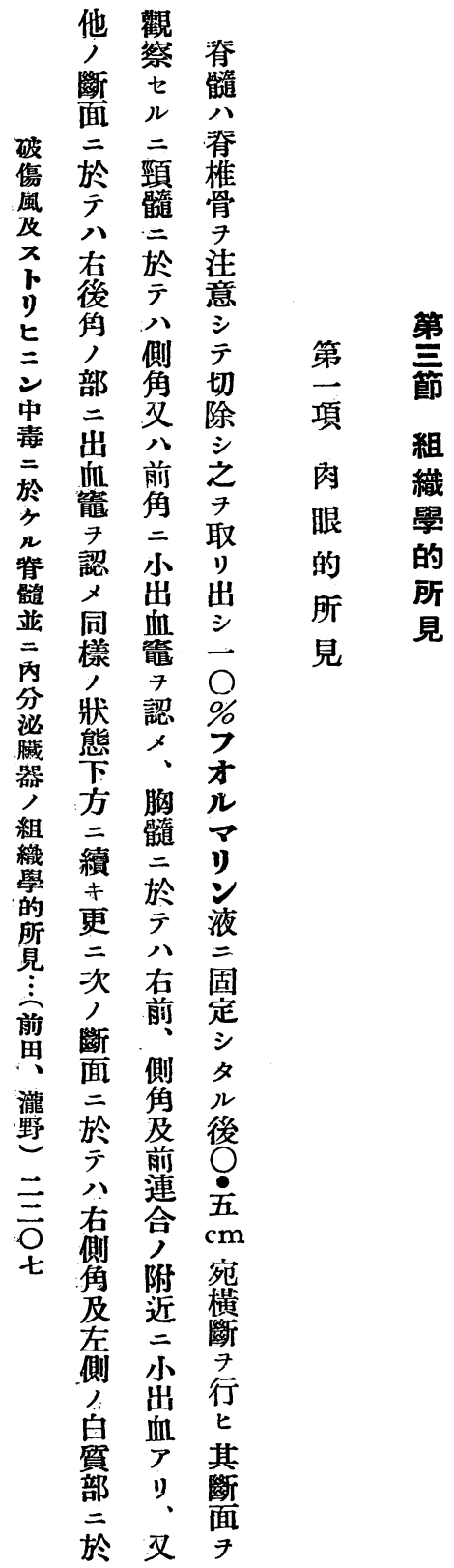


内現 胸

部 $v$ 㘕

及焦品

ビ前噼

其角質

圍 於

二

於 亏王

广

八後 白

神俑 質

經 $=$

要 於於

素 テ テ

问无

或强一

八キ 般

强出 $=$

万血 血

變 7 管

性 認 公

为充

或学 血

消 羔 赤

失 血 血

ス 篐球

ル, 7

者境 以

界 $\bar{~}$

》) 充

入八多

出多 サ

血少ル

䨨多壬

關 光大

聯,

七堆儿

ザ殖出

ル 血

白見八

蜸儿主

人一所卜

右 $>$

测り テ

方出烣

於血質
儿䩪 》

氏 染り 材

小色、料

脊體二工八

$=八$ 才

上新

乙蓧或復

七八染 木

手法 几

少 7 子

手行 D

比江

法丰液

行法背阅

行年固

施䖵定

”。軸經 う

索織 $v$

及, 策

細檢 儿

胞香者

内 $=$

原 至

㵶 リ テ

維 テ 天

$=八 工$

八諸 口

ビ 種

ルノヂ

染

色 包

ウ 埋

ス 行 法

*

I 5 . $\exists$

氏 $\bar{v}$

法。各切

及 染 片

ビ 色

カ 法 製

,

几缺主

氏 點

法 7 三

補 テ

行

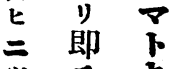

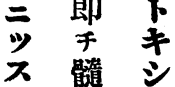

的

所

見

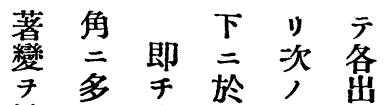

見多食示斷 血

ズ嘎八面筐破

胸 $=$ 斯 $=7$ 傷

檤 於力於見風

及

腰八著モモて

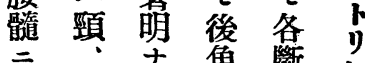

於胸角斷

级面 =

側 $尹$

最腰血角卡表

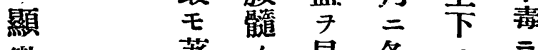

萌主見各貫於

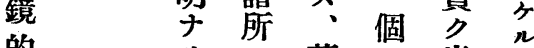

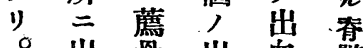

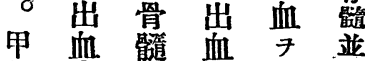

狀籠

腺 $尹$ 八 $x$

認肉更

腦 $x$ 眼 $三$ 腅

下之的次腰 器

垂等, 簿 ,

體, 出斷

出 血面 於 織

䀝 血 $7=\bar{\tau}$

臟䇫認白八的

副散 ゙ 後右前

腎在。㱏角剪

垔二虫 側

丸 三 管 角 瀧

等 $\bar{二} \quad$ 三野

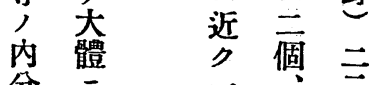

分泌於個前 方

藏 天

器 灰

$=$ 白

於 算

亏 特

$八=$

肉 前

眼 角

的 及

二 側

, 連公

出 合

血 $=$

筒 -

ア 個

》)

、出

》 血

上 䈐 


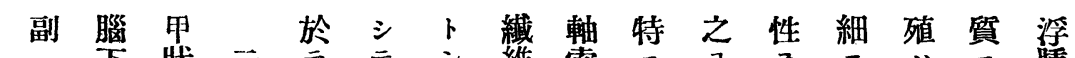

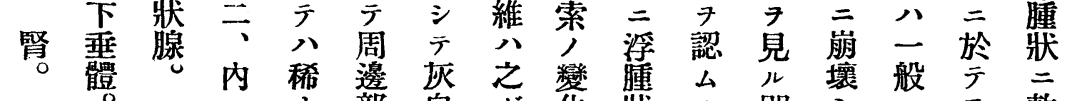

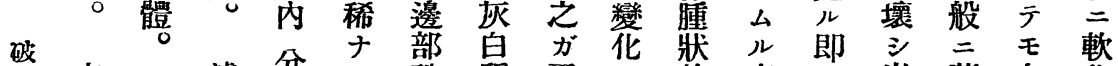

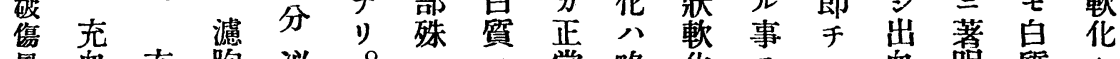

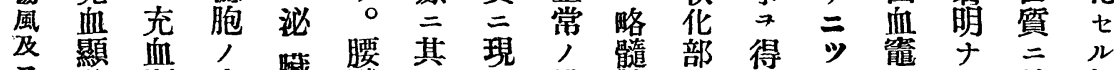

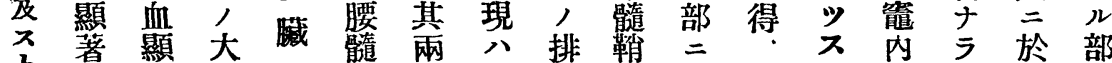

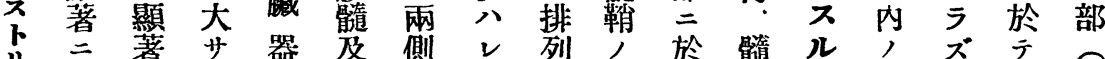

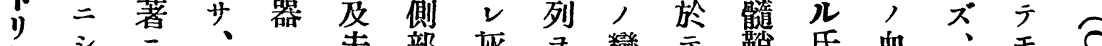

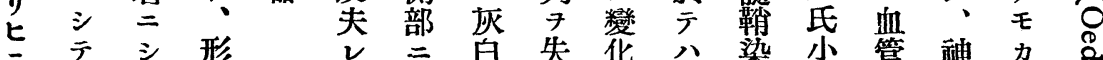
中 所 後 毒 二 葉 膠 於赤 於筫 $n$ 球 广 共

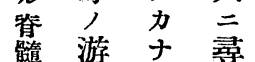
亚走り 常 丙大 $=$ 分見光 シ

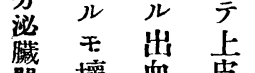
器壞 血皮 組 其

斌 其及

學著 黛 ビ

所變 蓄 核

見素變 曋

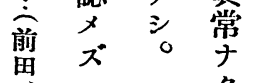

瀧

ク

野

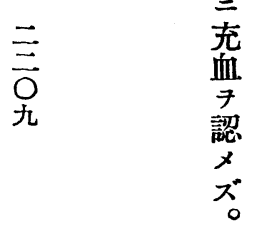

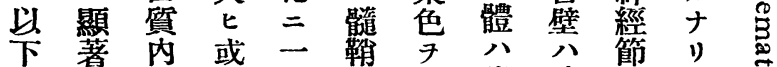
二, 分致公施諸硝細多范 於り神消入種七所哲胞數。

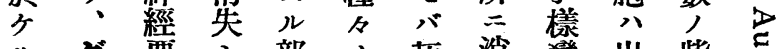

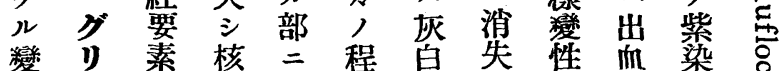

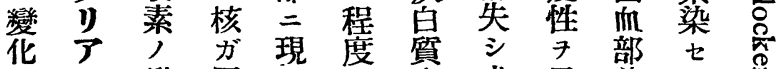

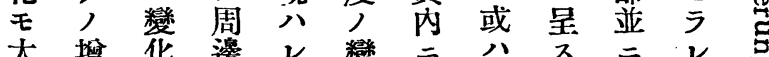

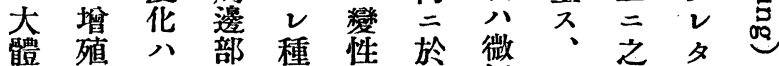
上公胸三方点細出三ルア 記萻簿移, 示八三血接小》

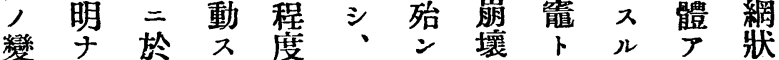
化ラタル即ド学離者り,

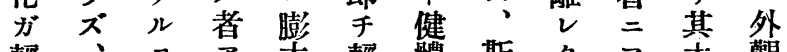

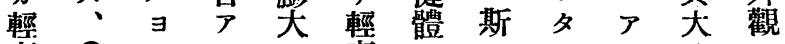
度 リ ⿱ ㇒一度

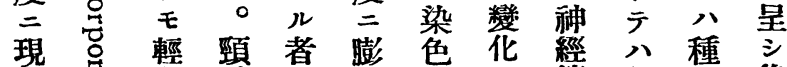

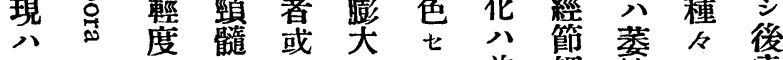
ル 二, 八スラ前細維ナ索

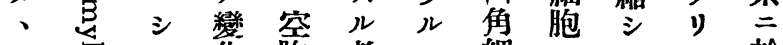

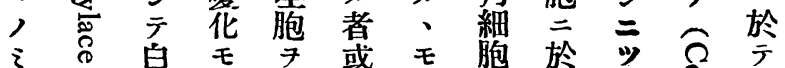

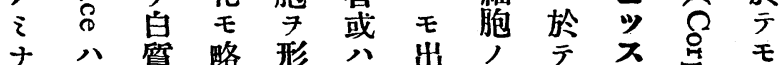

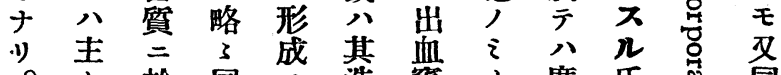
。卜於同不造筐ナ廣氏心同 シ テ 樣 少 構 内 ラ 沉 小

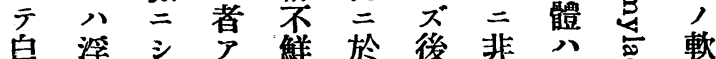

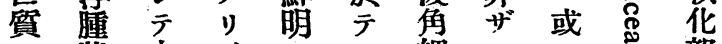

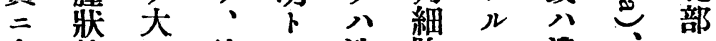

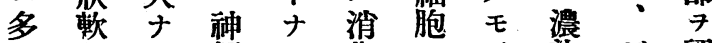

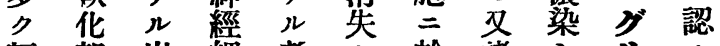

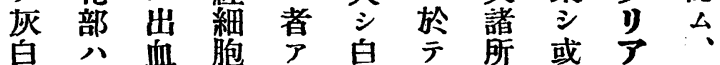

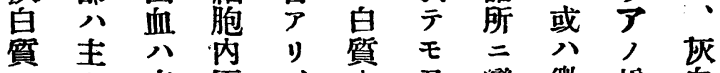

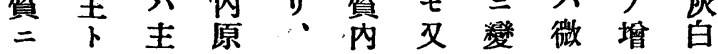


内現最 $フ コ$ 部

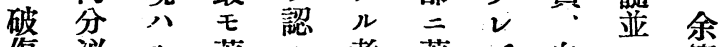
傷泌ル蓄么者蓄ズ帛二等 風藏儿明ル, 明㳄質内只 二 器 $モ=モ$ 如 $t=$, 分極 於二其 三出とリ帛兩泌

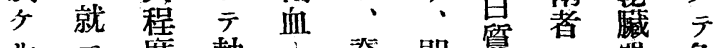

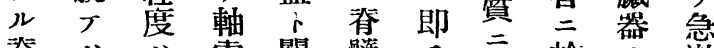

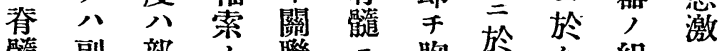

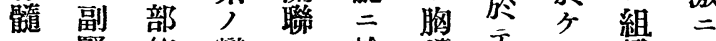
督位變せ於籍忈儿織死

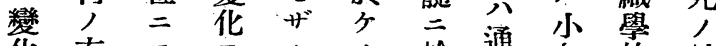

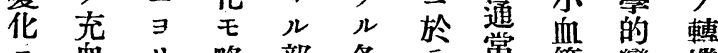

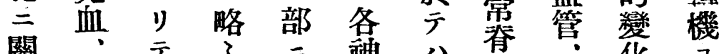

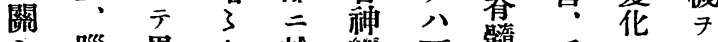

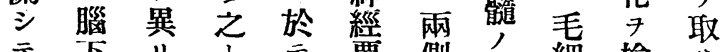

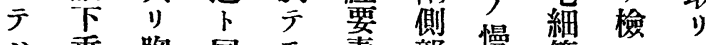

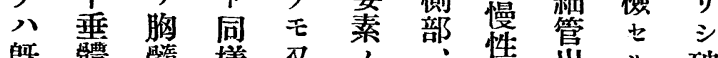

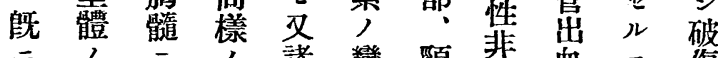

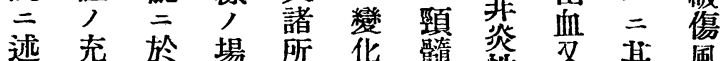

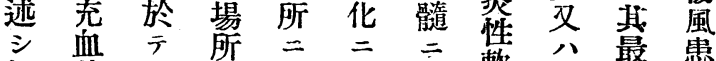

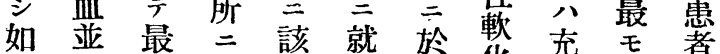

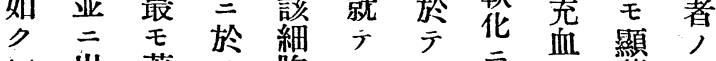

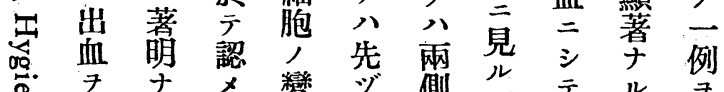

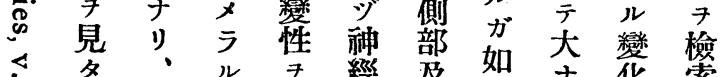

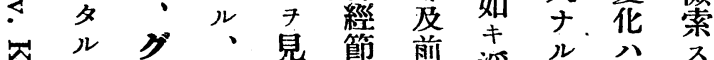

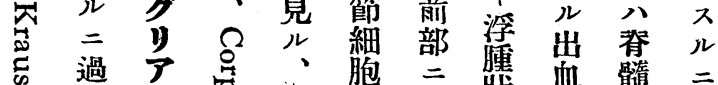

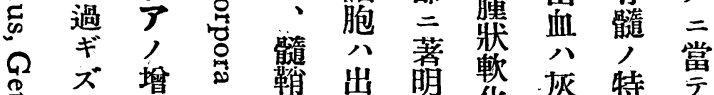

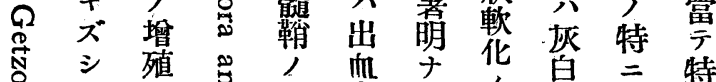

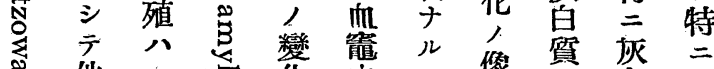

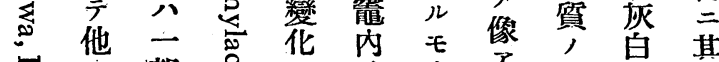

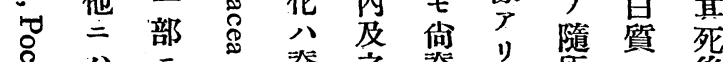

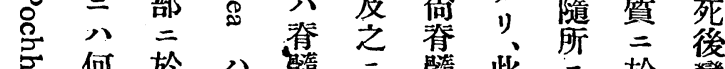

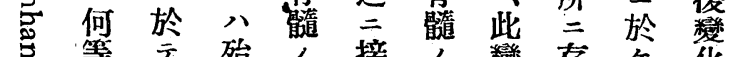
等立㱠自接学存名稚

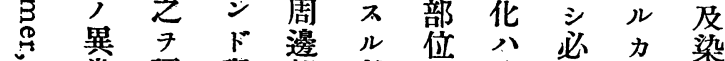
的常認春部者三主ズす色

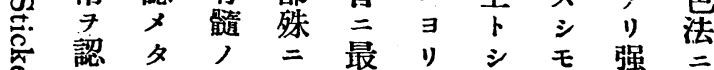

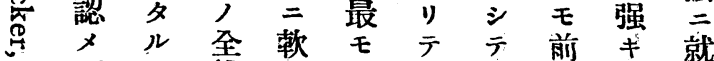
×

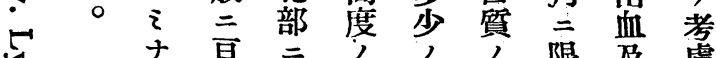

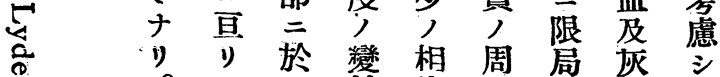

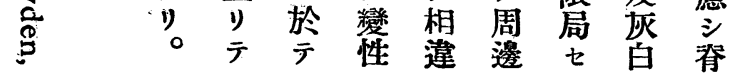

墨 胸 櫒

丸腺 藏

特著 充 破 充變盉風 血 シ 公 第枀出り 西出 7 節 血 認

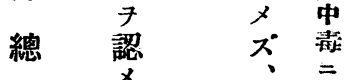
ズ 蓄 括 晠

シ

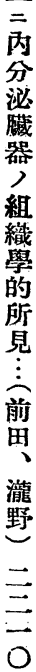


變 並風二

化二, 依動

二知 - $v$ 物

關 覺 例 バ二

破 ス䪭二中不

傷ル經於榀卜

風報細 テ 神り

及告胞脊 經 ヒ

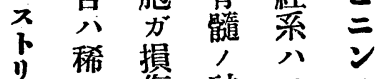

七ナ傷神スチ

こルセ經卢注

之 方 節 $\boldsymbol{~}$ 射

中 如 細 ヒ不

毒シ 、胞 こ

於余事變普破

分等 報䇤 业 破

笲分济

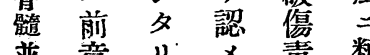

亚意 り、メ 毒 類

离人然り菜似

分泌破り シ 對少

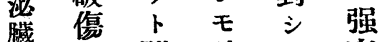

器風雖破テ面

, $モ$ 傷同性

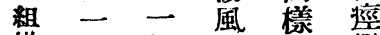

織 例 般 毒ナ攣

學 7 素ルチ

的檢 页势 發

質棠 占分毒 ス

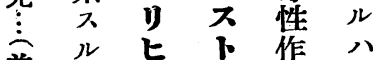

前 $=ヒ \mathfrak{~}$

思當 $ン$ 七知

瀧方二 二有人

野之依ンス事

キルチル實

三實 脊 動 者二

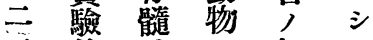

二 的聚 三 如

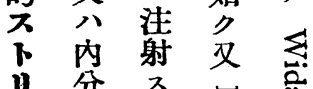

分

七汼

ソ人脊怘口

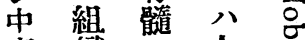

毒織 自 連 破

比的動傷
經 各 邑 キ 踓 Q 經

過種

各 合等 微 等 命 家

人症 指 細 先导 於 号

個 影摘 點 報官定4

性 影 七 點 報 0 定

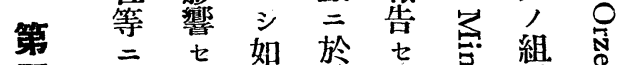

三

前す 諸 事風 䒜

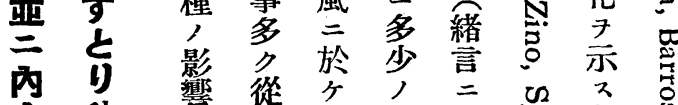

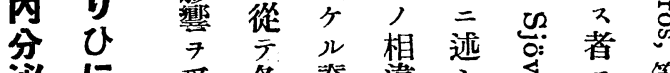

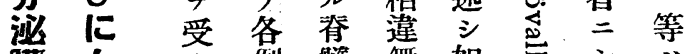

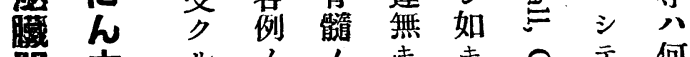

器中心片キ

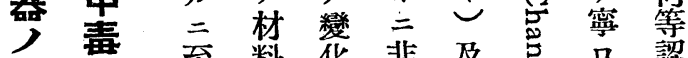

組 至料化韭及总口認

識於

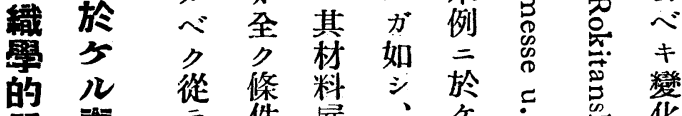

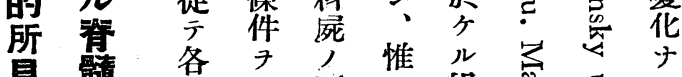

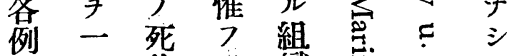

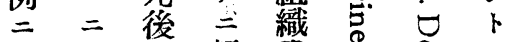

$\exists 7$ 紮 既 學

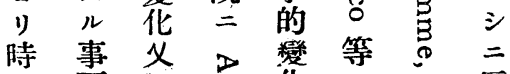

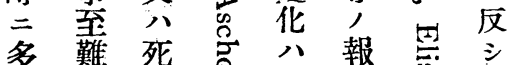

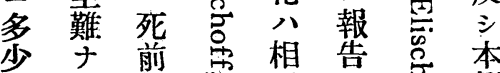

儿二於百三豆例

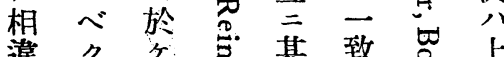

造 ク 更 少

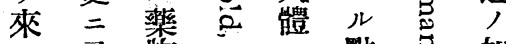

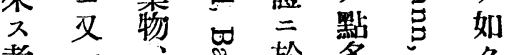

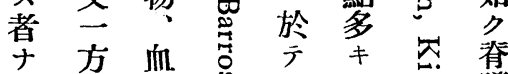

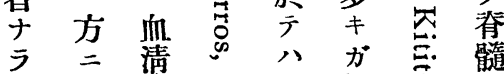

於療可至如怘?

力

毒 否 力、 


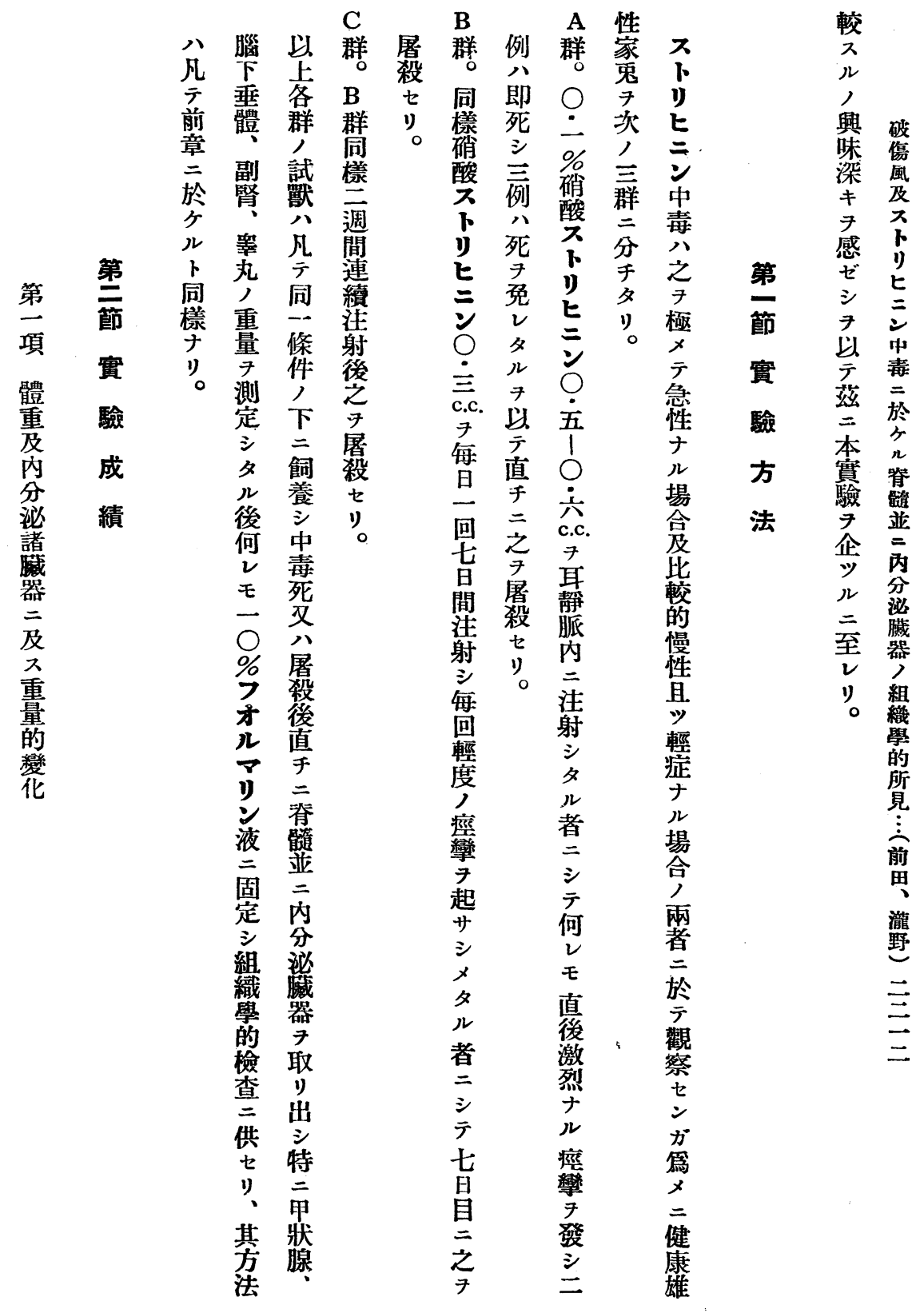




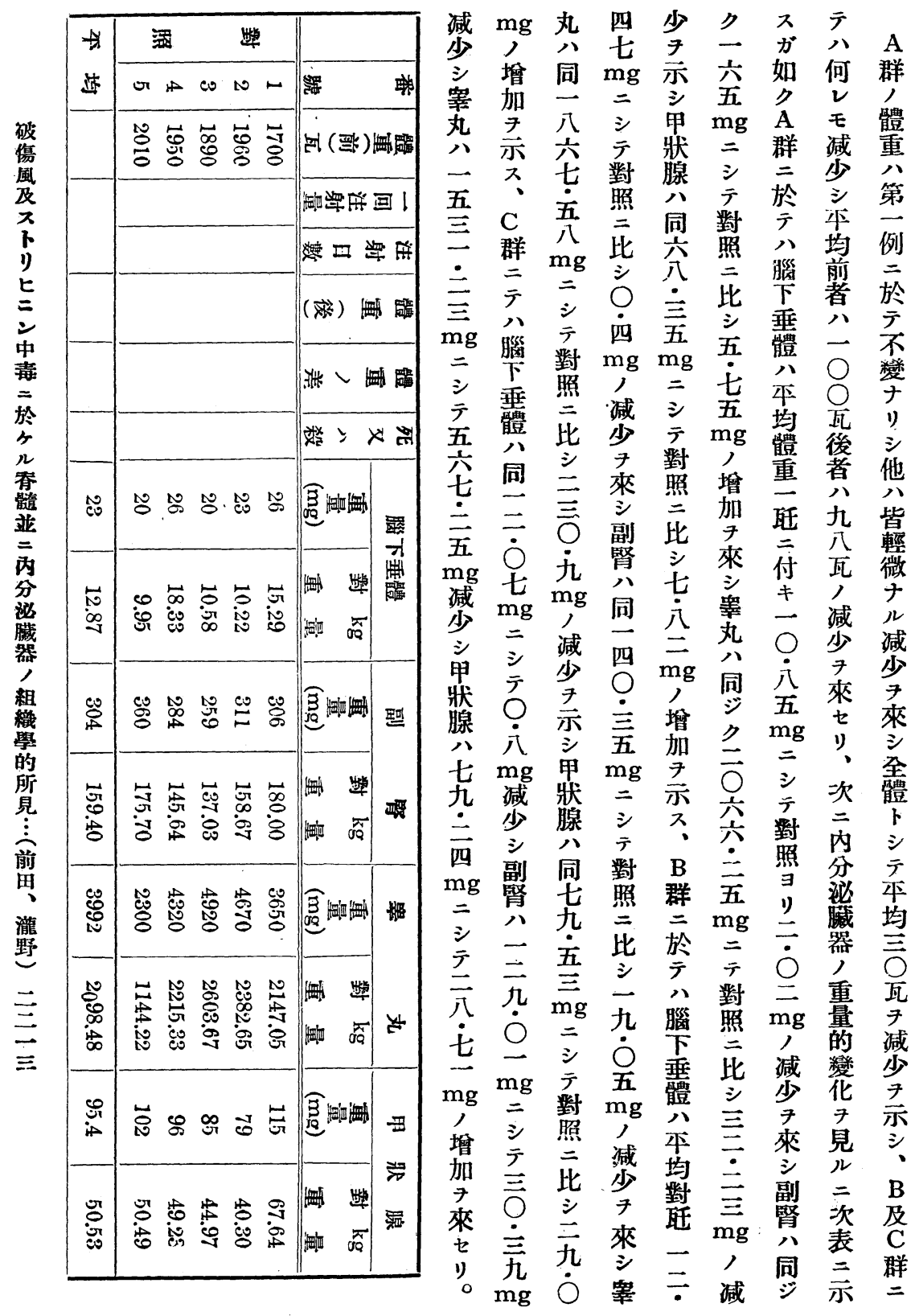




\begin{tabular}{|c|c|c|c|c|c|c|c|c|}
\hline 巏 & 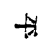 & 望。 & 呪 & $+t$ & 䵩 & 崰 & $\Rightarrow$ & 慗 \\
\hline 8 & 近 & $r A \infty N$ & 野 & 造 & $G \Delta \infty N-$ & 策 & 道 & $\sigma A \omega N$ \\
\hline & \begin{tabular}{l}
1 \\
$\mathbb{0}$ \\
\hdashline
\end{tabular} & $\begin{array}{lll}N & N & N \\
\end{array}$ & & $\ddot{\ddot{g}}$ & 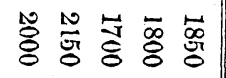 & & 量 & 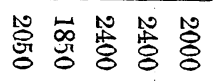 \\
\hline & & 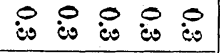 & & & 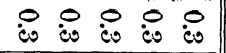 & & & 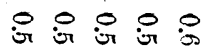 \\
\hline & & 吉占占占占 & & & 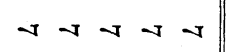 & & & $\sim \sim \sim H \sim$ \\
\hline & $\begin{array}{l}0 \\
0 \\
0\end{array}$ & 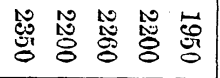 & & $\stackrel{\circ}{8}$ & 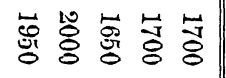 & & $\stackrel{ }{\vec{G}}$ & 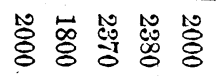 \\
\hline & $\underset{\infty}{1}$ & & & $\begin{array}{l}1 \\
\overrightarrow{8} \\
\end{array}$ & & & 1 & \\
\hline & & $s=s=$ 朕 & & & $s=s=8$ & & & 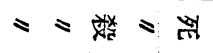 \\
\hline & $\underset{N}{N}$ & $\cong$ & & No & 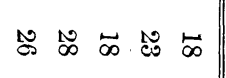 & & $\begin{array}{c}\text { No } \\
\text { N } \\
\infty\end{array}$ & 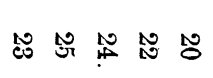 \\
\hline $\begin{array}{l}1 \\
0 \\
\dot{0}\end{array}$ & t. & 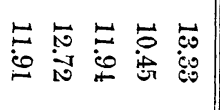 & $\begin{array}{l}1 \\
\text { b } \\
\text { aे }\end{array}$ & $\begin{array}{l}\vec{v} \\
\stackrel{\vec{v}}{*}\end{array}$ & 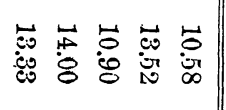 & $\begin{array}{l}1 \\
1 \\
0 \\
0 \\
0\end{array}$ & 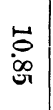 & 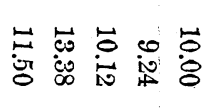 \\
\hline & $\stackrel{\infty}{\infty}$ & \&̊ㅇ & & $\underset{i=}{\stackrel{N}{心}}$ & 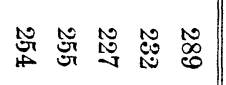 & & $\ddot{\sim}$ & 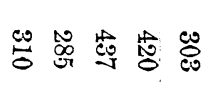 \\
\hline 1 & 芯 & 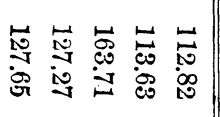 & 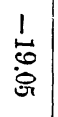 & 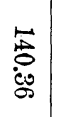 & 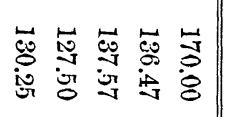 & 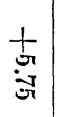 & 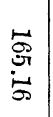 & 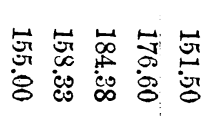 \\
\hline & 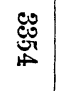 & 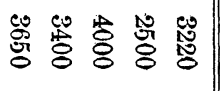 & & 这 & 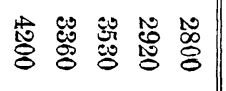 & & 苦 & 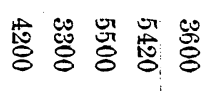 \\
\hline 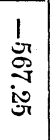 & 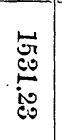 & 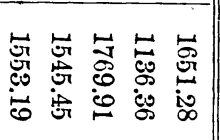 & $\begin{array}{l}1 \\
1 \\
0 \\
0 \\
8 \\
8\end{array}$ & 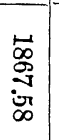 & 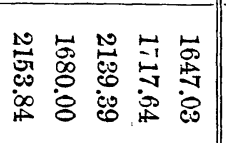 & 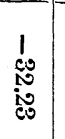 & 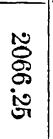 & 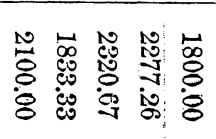 \\
\hline & 可 & 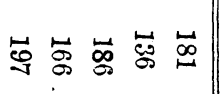 & & 营 & 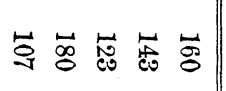 & & 点 & 苛怘总苛忠 \\
\hline \begin{tabular}{l}
+ \\
$\substack{\infty \\
\infty \\
\hdashline}$
\end{tabular} & $\begin{array}{l}-1 \\
01 \\
10 \\
10\end{array}$ & 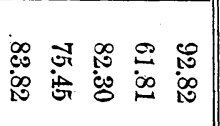 & $\begin{array}{l}+ \\
\vdots \\
: \\
8\end{array}$ & : & 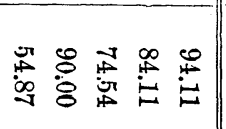 & $\underset{\substack{+\infty \\
0 \\
0}}{+}$ & $\begin{array}{l}\infty \\
\infty \\
\text { sivi }\end{array}$ & 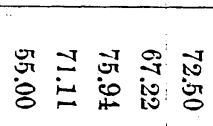 \\
\hline
\end{tabular}


B

A

本 ガ 出 々 鞘 群 多右第般 血出群一

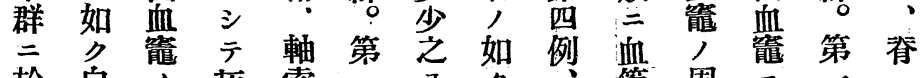

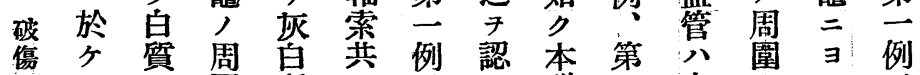

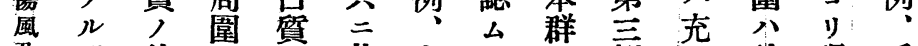
及 變 軟 三三其白 $三$ 例血神强毛 花化 於 於程質卜於卜不經り 細

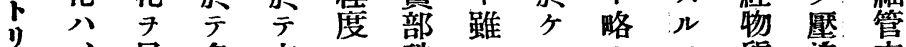

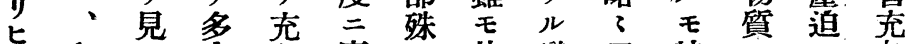

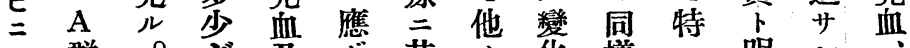

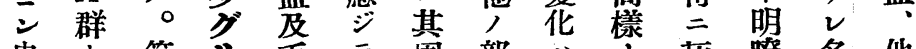
中卜 第 $\boldsymbol{y}$ 毛 $匚$ 周部 八广灰暸多他

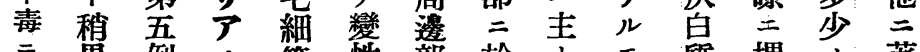
翞例, 管性部於卡筫堺人, 著

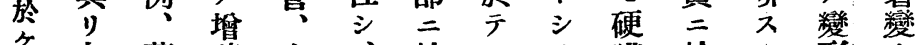

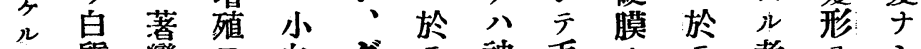

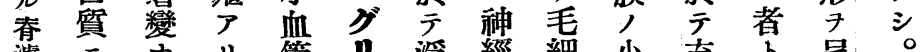
濾云ナり管り浮經細小充皇呈。

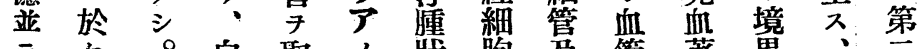

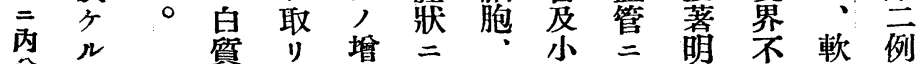
分變 卷 殖 軟二血强二明膜

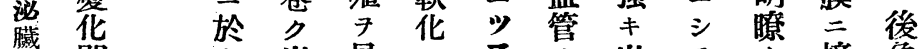

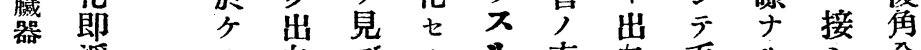

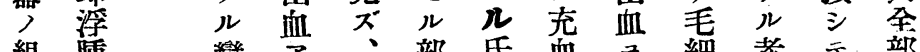

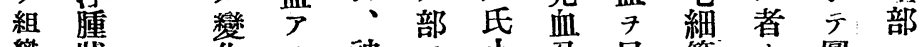
織牀花》神了少又見管卜圓二 學軟、、經り體分ル户形占 的化 前出箁其・出、周り、細么

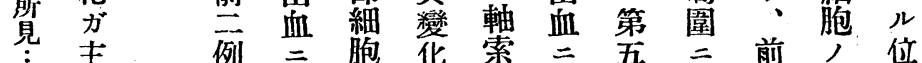

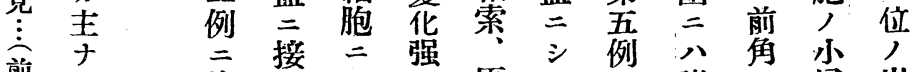
前ル比不前原亏諸二浸出

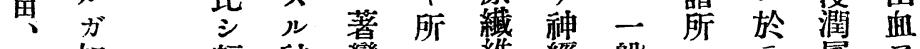

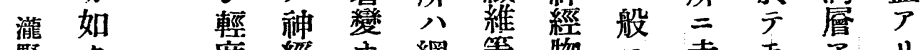

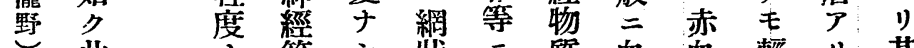
些節 三 狀三筫血血輕り、其 三變り細。”著, 管球度、出 三化：。胞第外變變充了方硬 血

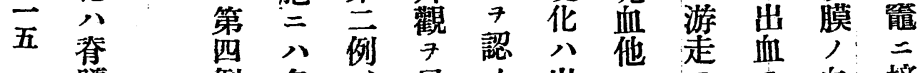
䯘例多是 $x$ 出

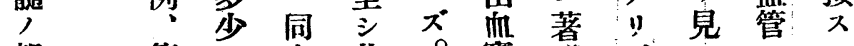

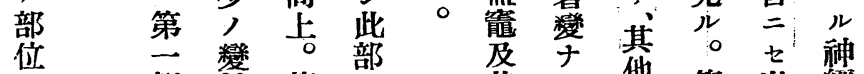
二 例 性 第 於 其 三 著 第 出 經

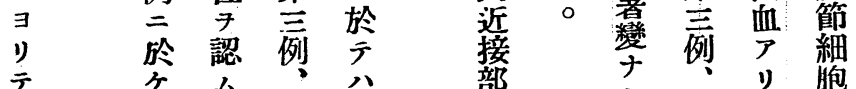

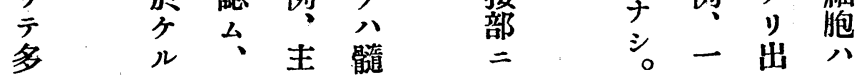




\begin{tabular}{|c|c|c|c|c|c|}
\hline & 群 & & A & & \\
\hline 例五第 & 例四第 & 例三第 & 例二第 & 例一第 & \\
\hline $\begin{array}{l}\text { 同 } \\
\text { 上 }\end{array}$ & $\begin{array}{l}\text { 同 } \\
\text { 上 }\end{array}$ & $\begin{array}{l}\text { 同 } \\
\text { 上 }\end{array}$ & $\begin{array}{l}\text { 同 } \\
\text { 上 }\end{array}$ & $\begin{array}{l}\text { 著 } \\
\text { 變 } \\
ナ \\
⿱ 亠 䒑\end{array}$ & $\begin{array}{l}\text { 䀝 } \\
\text { 垂 } \\
\text { 體 }\end{array}$ \\
\hline $\begin{array}{l}\text { 同 } \\
\text { 上 }\end{array}$ & $\begin{array}{l}\text { 著 } \\
\text { 變 } \\
ナ \\
\text { シ }\end{array}$ & 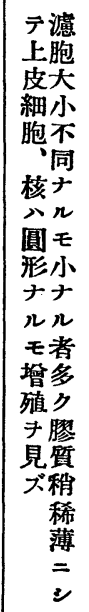 & $\begin{array}{l}\text { 前 } \\
\text { 例 } \\
= \\
\text { 同 } \\
\text { 吚 }\end{array}$ & 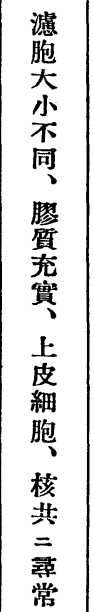 & \begin{tabular}{|c} 
甲 \\
狀 \\
腺
\end{tabular} \\
\hline $\begin{array}{l}\text { 前 } \\
\text { 例 } \\
= \\
\text { 同 } \\
\text { 新 }\end{array}$ & 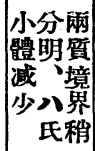 & 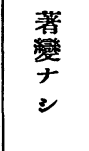 & $\begin{array}{l}\text { 體明䨗 } \\
\text { 䙿 } \\
\text { 常八界 } \\
\text { 小不 }\end{array}$ & 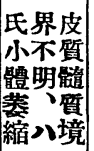 & $\begin{array}{l}\text { 胸 } \\
\text { 腺 }\end{array}$ \\
\hline 上 & $\begin{array}{l}\text { 同 } \\
\text { 上 }\end{array}$ & $\begin{array}{l}\text { 同 } \\
\text { 上 }\end{array}$ & $\begin{array}{l}\text { 同 } \\
\text { 上 }\end{array}$ & $\begin{array}{l}\text { 著 } \\
\text { 變 } \\
\text { ナ } \\
\text { シ }\end{array}$ & $\begin{array}{l}\text { 副 } \\
\text { 腎 }\end{array}$ \\
\hline $\begin{array}{l}\text { 同 } \\
\text { 上 }\end{array}$ & $\begin{array}{l}\text { 同 } \\
\text { 上 }\end{array}$ & 上 & $\begin{array}{l}\text { 同 } \\
\text { 上 }\end{array}$ & $\begin{array}{l}\text { 著 } \\
\text { 變 } \\
\text { ナ } \\
\text { シ }\end{array}$ & 膆 \\
\hline $\begin{array}{l}\text { 同 } \\
\text { 上 }\end{array}$ & $\begin{array}{l}\text { 同 } \\
\text { 上 }\end{array}$ & $\begin{array}{l}\text { 著 } \\
\text { 管 } \\
\text { ナ } \\
\text { シ }\end{array}$ & $\begin{array}{l}\text { 血 } \\
\text { 管 } \\
\text { 聟 } \\
\text { 充 } \\
\text { 血 }\end{array}$ & $\begin{array}{l}\text { 著 } \\
\text { 變 } \\
\text { ナ } \\
\text { シ }\end{array}$ & $\begin{array}{l}\text { 昱 } \\
\text { 丸 }\end{array}$ \\
\hline
\end{tabular}

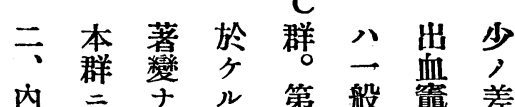

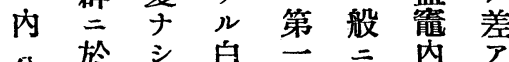

分於 シ 白 - 内 $\bar{~}$

分。質例 $\exists=$ 》傷

泌儿第公、於、風

瀻變四甚著保䇣持 八而 及

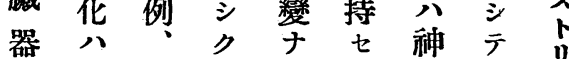

大白浮 シ ラ 經 浮 ヒ

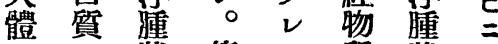

於多牀第二䫓牀衣

テ䒚 軟 例 ス 壞 化 毒

B 浮化、几 死部 =

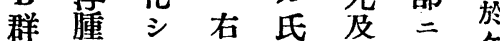

卜牀、䇣小消ア只

同) グ角體先り春

樣 軟 リ $コ$ ・

ナ化学り細見八並

ルチ, 後胞棸軸 离

沜增掌㐫之掌分

如 殖 三原 三永

シ 97 亘瀻近骨遀藏

第見出維 接鞘 器

例、血共ル綡租

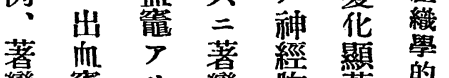

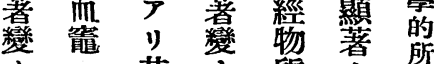

ナ二其質質

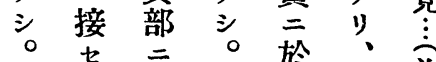

七 於 0 於立

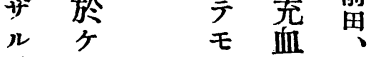

神 ル多及 瀧

經 神少出野

節經少血

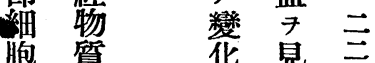

二小公

八軟》

著 化 然第

變 辛

シ 血 モ,

○簡神 $i$

第, 經 二

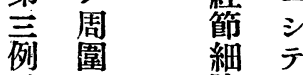

⼆ 胞 其 


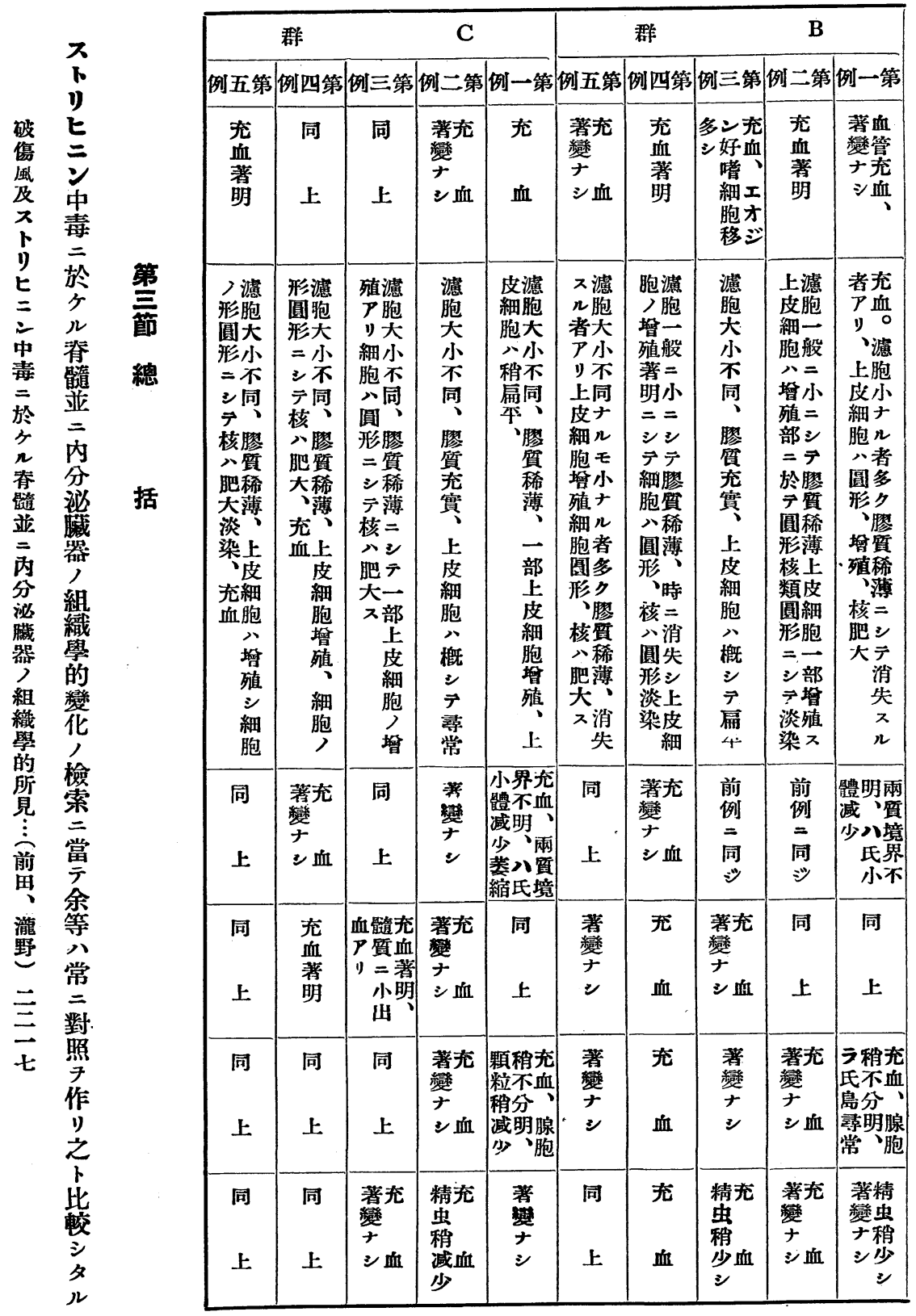




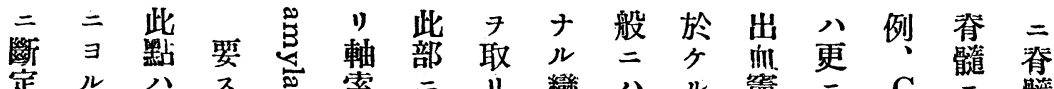

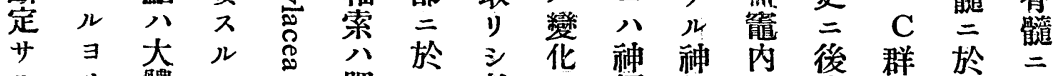
ルリ體二八萌テ者卜經經二索第々於破

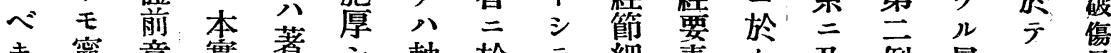

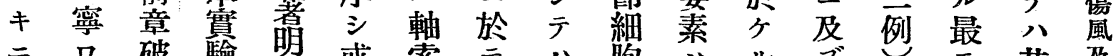
二口破驗明或索亏八胞公ルラ゙焦及 非出傷二ナ公屡 ル血風 $\exists$ 空膸之般八管学三奛經卜

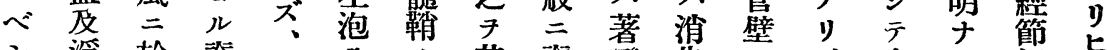
浮於脊

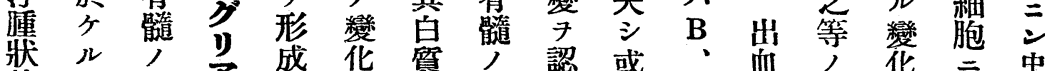

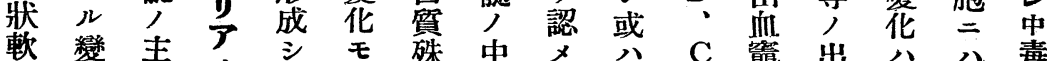
化花主神无殊中

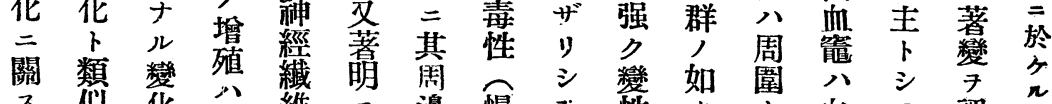
入似花 二維二邊慢孔性名血厅認管

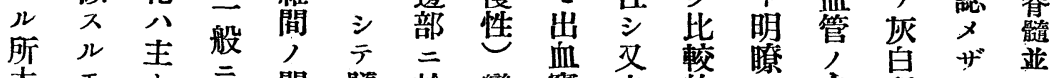

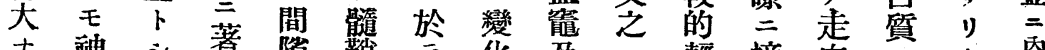

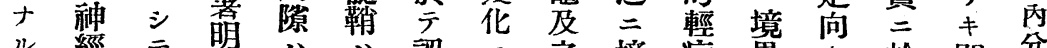
儿經テ琞八分認三之接症界於即分

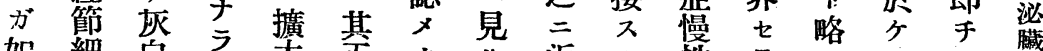
如細泉

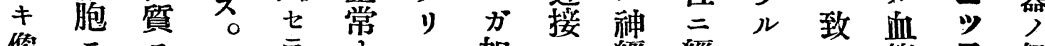
像三 三 方 呈一船群浮部胞七泉充學

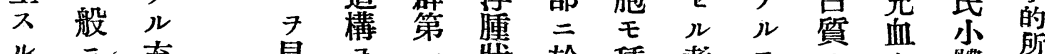

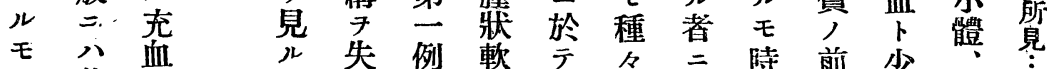

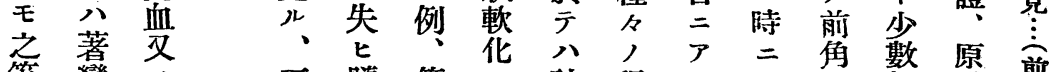

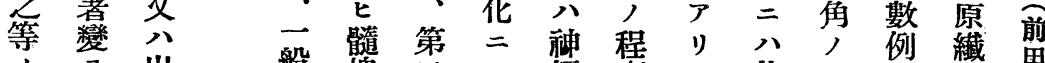
子出 關 見血 係 ズ 素繋皇 $\exists$ 及

り膸 於 本 豧 々 實

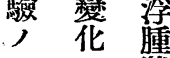

i $八$ 狀

二 神 軟

ヨ. 經 化

リ 節 $=$

直 細 シ

于 胞 テ

般 塊 至 シ 經 度 テ 其

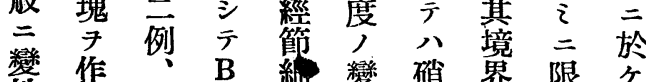

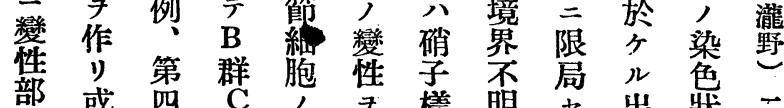

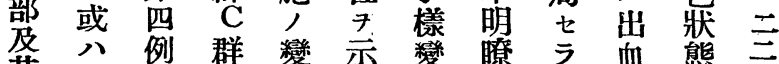

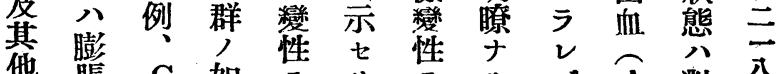

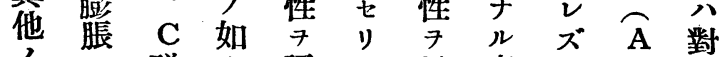
部 群キ認、呈事 シ 群照 部或第比

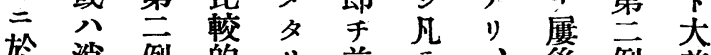

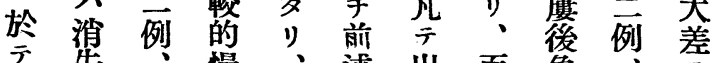
只失慢、述出而角等

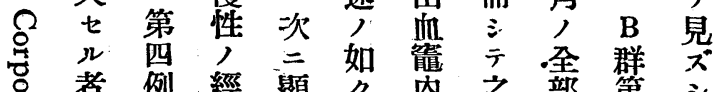

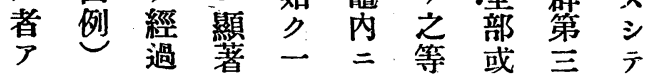




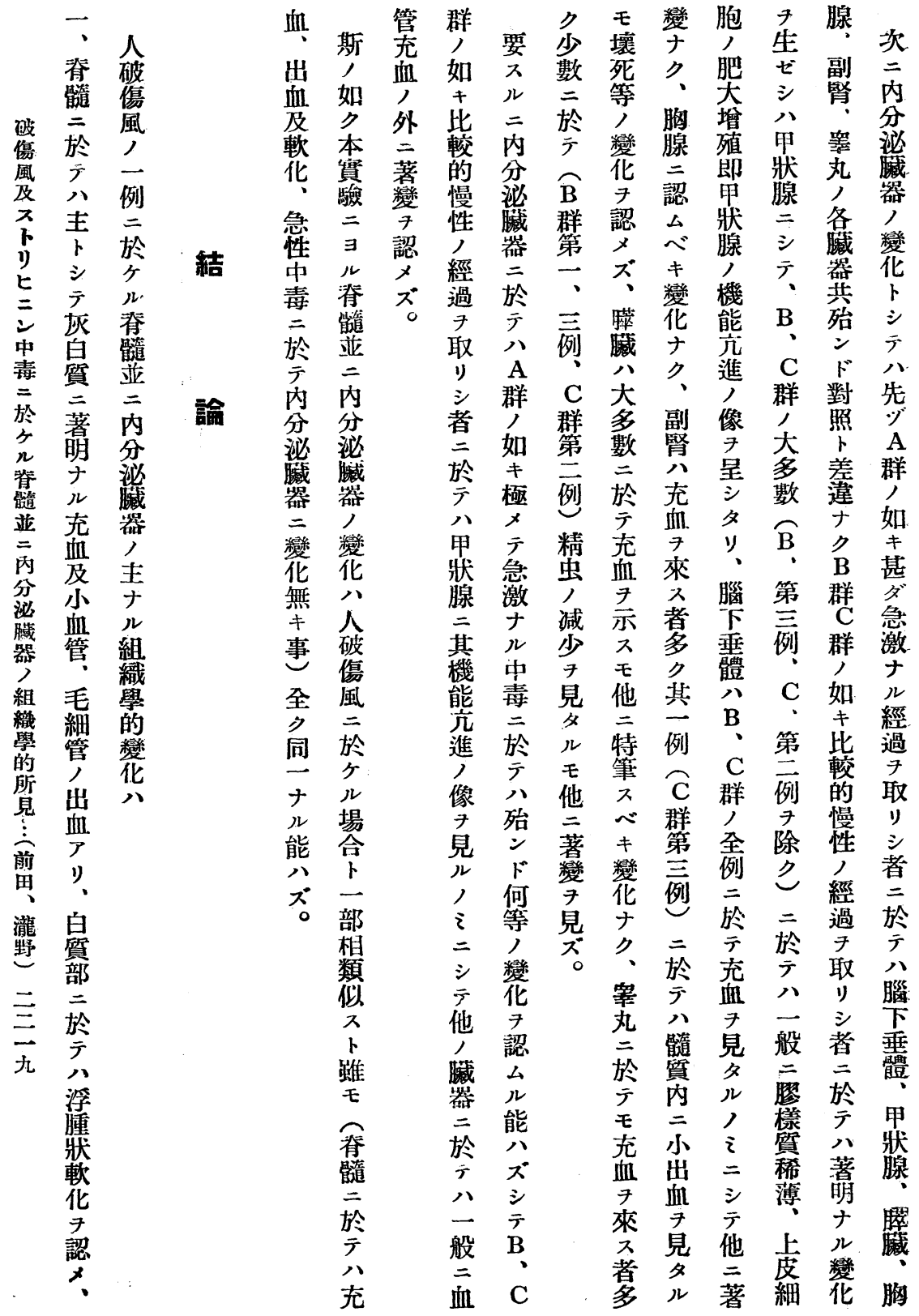




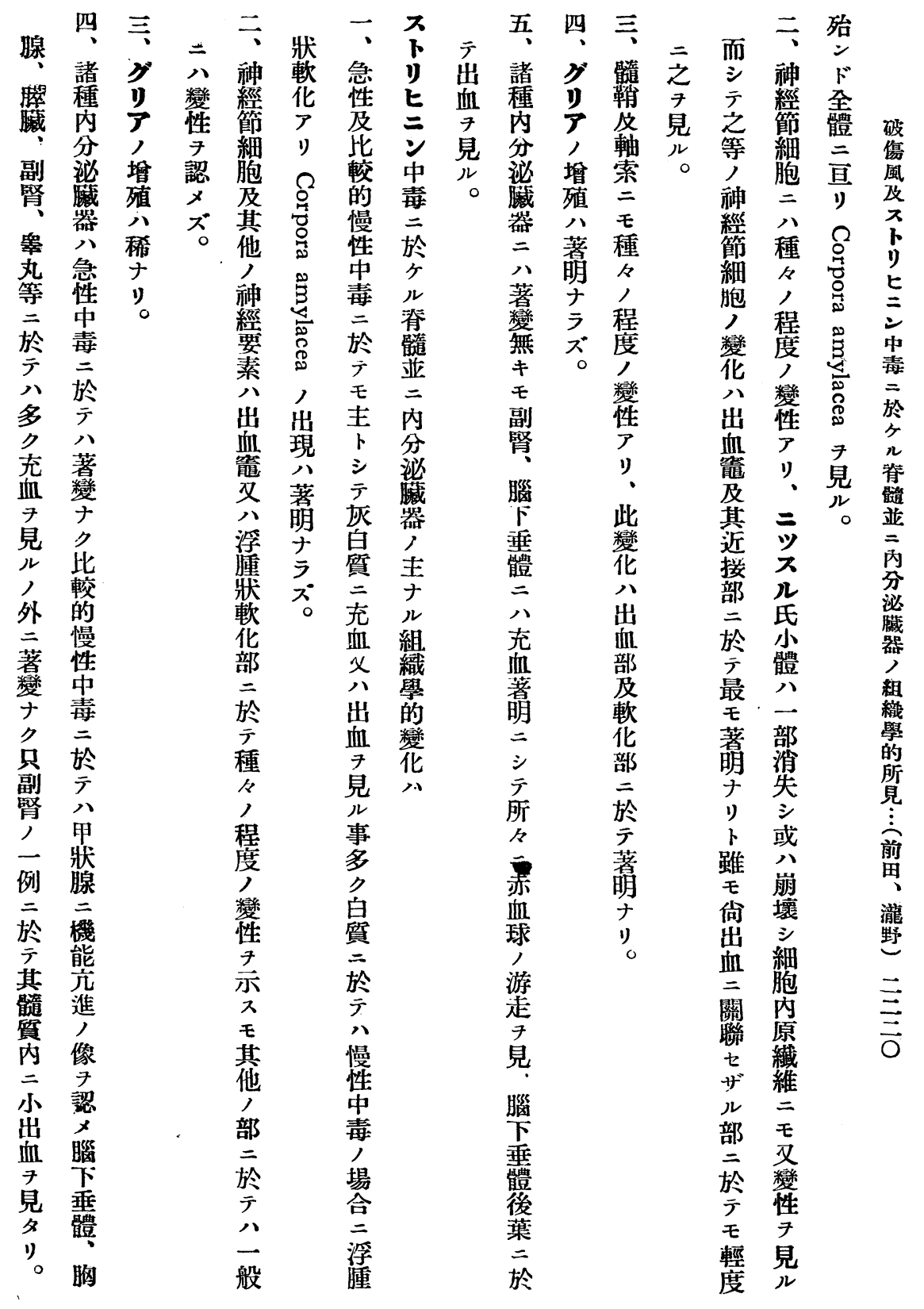




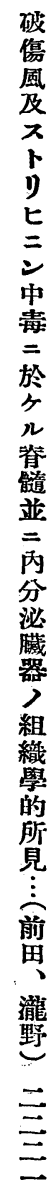
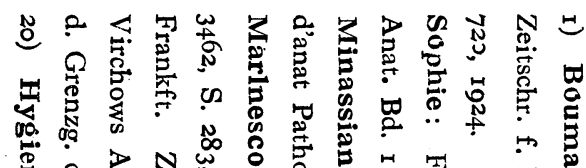

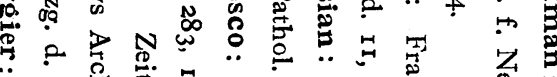

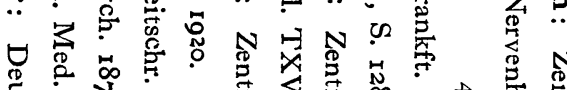

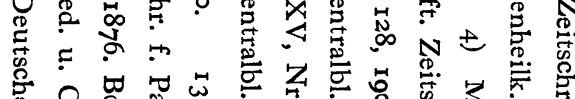

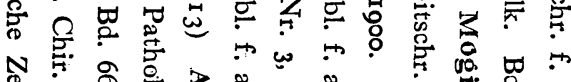

N.

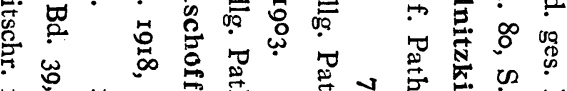

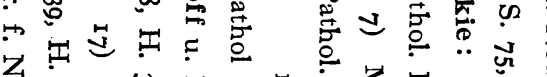

旁

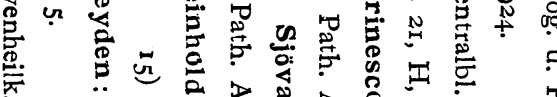

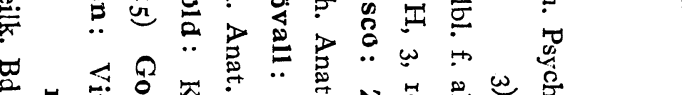

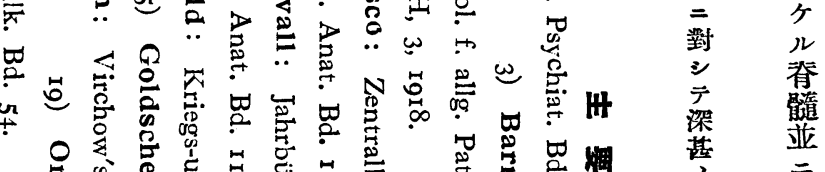

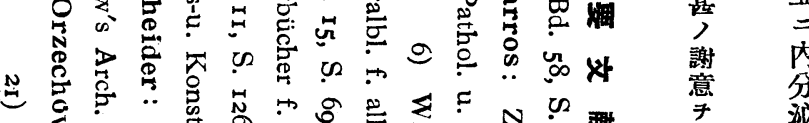

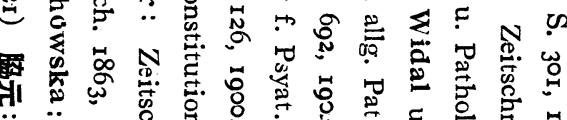

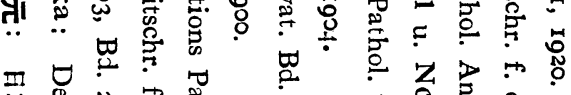

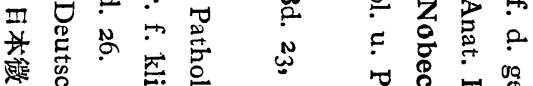

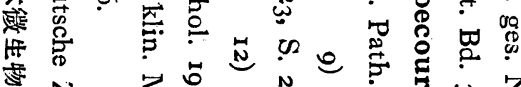

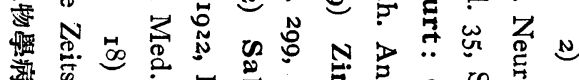

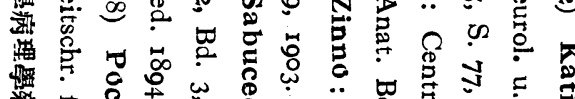

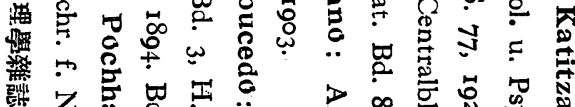

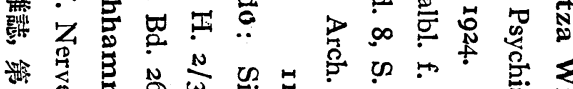

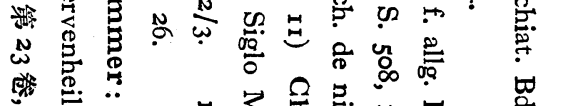

雅

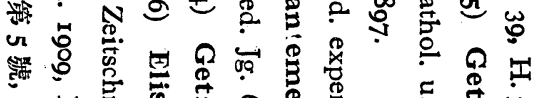

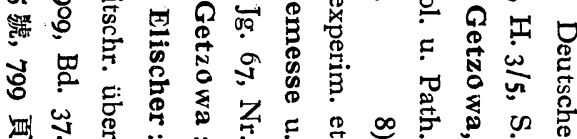

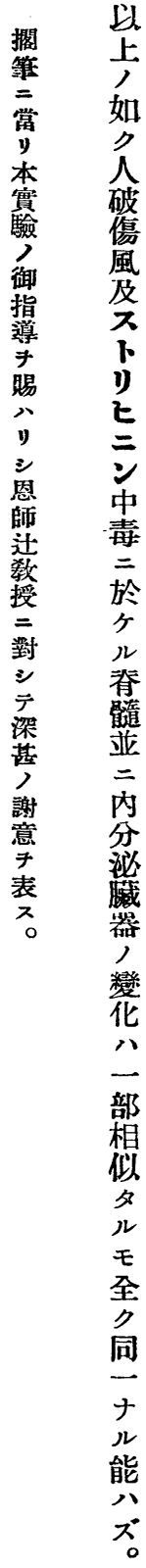




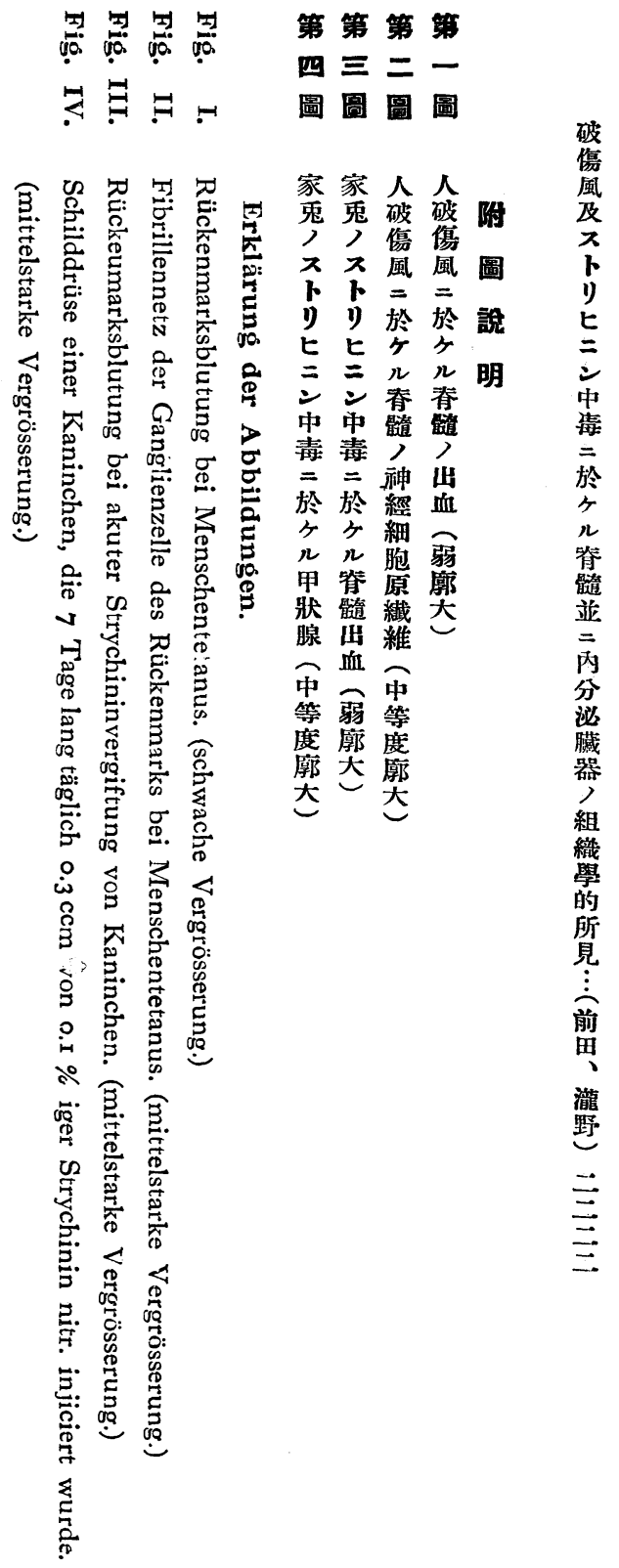


圖附文論野㴰 - 田前
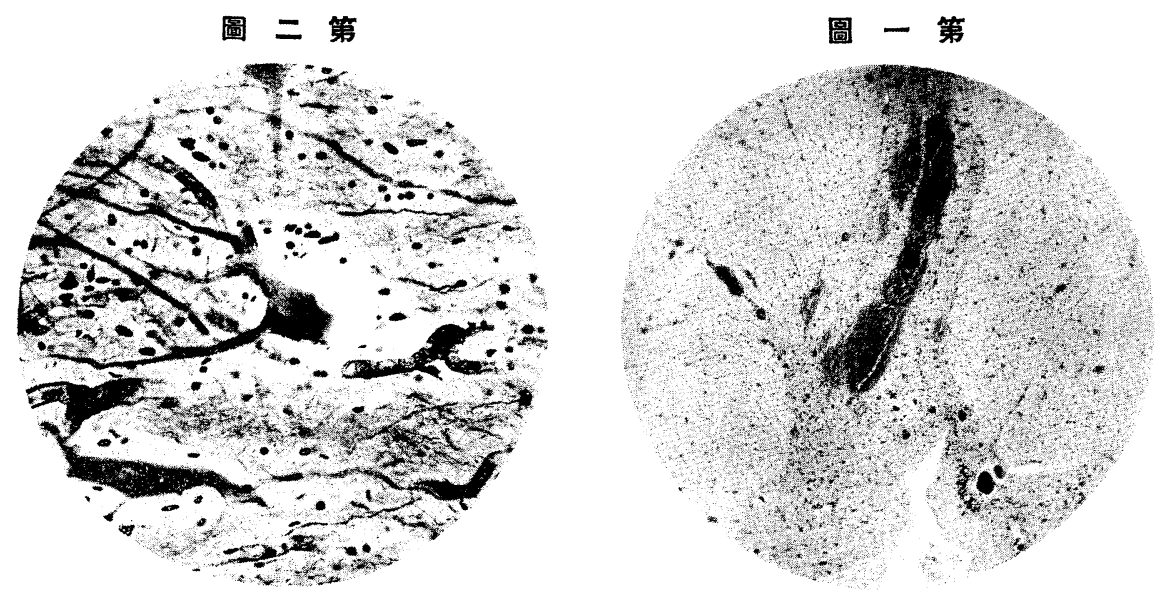

圖 四 第

圆 三第
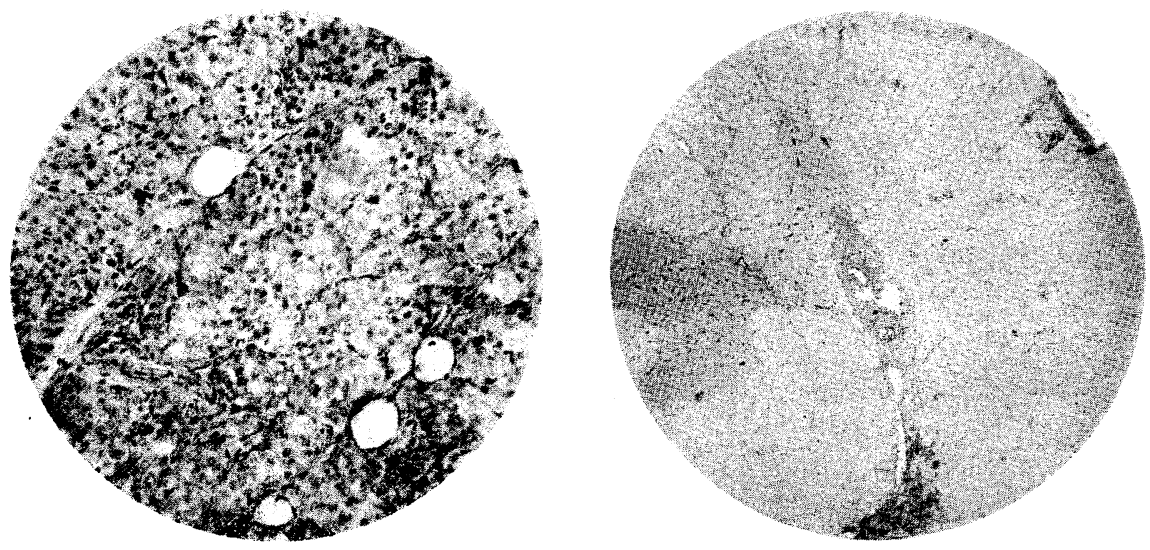
ana phylaxieblutbild durch die einzelnen oder die kombinierten Einwirkungen von Schilddrüsenfütterung,-exstirpation, Adrenalin und Atropin beeinflusst.

(Autoreferat)

\section{Ueber die histopathologischen Veränderungen des Rückenmarks und der innersekretorischen Organe bei einem Fall von Menschentetanus sowie bei der Strychninvergiftung von Kaninchen.}

\section{Von}

Dr. H. Mayeda und Dr. M. Takino.

(Aus der I. med. Klinik der Kaiserl. Univers. zu Kyoto, Japan. Direktor: Prof. Dr. K. Tsuji.)

Die Resultat lassen sich kurz wie folgt zusammenfassen.

A. Bei einem Fall von Menschentetanus.

I. Die Hyperämie und die Kapillaren- und Arteriolenblutungen sind überall, hauptsächlich aber in der grauen Substanz, zu sehen. Doch ist der Blutungsgrad je nach der Lokalisation im Rückenmark verschieden. Er ist am stärksten im Brustmark. Ausserdem findet sich in der weissen Substanz des Rückenmarks hier und dort ödematöse Erweichung, die schon bei verschiedener toxischer Veränderung des Rückenmarks von vielen Autoren angegeben worden ist. Was das Auftreten der Corpora amylacea anbetrifft, so sind diese überall festzustellen, besonders an den stark degenerierten Stellen des Rückenmarks.

2. Die Ganglienzellen sind sowohl an dem Vorderhorn als auch an dem Hinterhorn degeneriert, indem die Nisslschen Körperchen bald fein zersetzt, bald miteinander verbackt und endlich ganz verschwunden sind. Nach unseren genauen Untersuchungen zeigen auch die intrazellulären Fibrillennetze 
verschiedene Veränderungen, $d . h$. die Fibrillennetze haben entweder ihre normale Anordnung verloren oder sind teils oder total verschwunden. Vakuolenbildung ist innerhalb der Ganglienzellen selten nachzuweisen. Diese obenerwähnten Veränderungen der Ganglienzellen sind natürlich innerhalb der Blutungsherde oder in der Nähe davon am stärksten. Aber sie kommen, wenn auch leichtgradig, selbst dort vor, wo von den Blutungsherden nichts $\mathrm{zu}$ sehen ist.

3. Die Degeneration der Achsenzylinder und der Markscheide ist verschieden, natürlich am stärksten innerhalb der Blutungsherde oder in der Nähe davon.

4. Die Gliazellen sind nicht deutlich gewuchert.

5. Die innersekretorischen Organe zeigen keine besonderen Veränderungen. In der Nebenniere und Hypophyse fällt die Hyperämie auf und sind stellenweise einige Erythrocyten aus den Kapillaren ausgewandert. Nur in den Hinterlappen der Hypophyse ist ziemlich ausgedehnte Blutung nachweisbar.

B. Bei der Strychninvergiftung der Kaninchen.

I. Bei akut oder auch verhältnismässig chronisch verlaufenden Fällen von Strychninvergiftungen stösst man auf Hyperämie und Blutung hauptsächlich in der grauen Substanz, während an manchen Teilen der weissen ödematöse Erweichung nachzuweisen ist. Von den Corpora amylacea ist nicht viel zu sehen.

2. Die Ganglienzellen sind innerhalb der Blutungsherde und in der Nähe davon verschieden degeneriert, während sie an den blutungsfreien Stellen des Rückenmarks gut erhalten sind. Kurz gesagt, steht die Degeneration der Ganglienzellen hierbei mit der Blutung in der grauen Substanz in einem bestimmten $\mathrm{Zu}-$ sammenhang.

3. Die Gliazellen sind nicht besonders gewuchert.

4. Bei den akut verlaufenden Fällen zeigen die innersekretorischen Organe keine besonderen Veränderungen, während bei den verhältnismässig chronisch verlaufenden nur an den Schilddrüsen ein histologisches Bild festzustellen ist, wie man es bei 
der Hyperfunktion der Schilddrüse beobachtet. An den übrigen innersekretorischen Organ, wie z. B. an Hypophyse, Thymus, Pankreas, Nebenniere und Hoden, ist Hyperämie nachweisbar. Nur in einem Fall fand sich in der Marksubstanz der Nebenniere ein kleiner Blutungsherd.

(Autoreferat)

\section{Ueber die histopathologischen Veränderungen des Rückenmarks und der innersekretorischen Organe bei der Tetanustoxinvergiftung von Kaninchen.}

\section{Von}

Dr. H. Mayeda und M. Takino.

(Aus der I. med. Klinik der Kaiserl. Univers. zu Kyoto, Japan. Direktor : Prof. Dr. K. Tsuji.)

I. In den meisten Fällen findet sich in der grauen und weissen Substanz Hyperämie, jedoch nur selten Blutung.

Was die Degeneration der Ganglienzellen anbetrifft, so stösst man auf sie sowohl bei den akuten Fällen als auch bei den chronischen.

Es sind nämlich die Nisslschen Körperchen bald fein zersetzt, bald miteinander verbackt, bald überhaupt nicht mehr vorhanden. Auch fällt stellenweise Vakuolenbildung in die Augen. Die Zellfortsätze der Ganglienzellen sind bald dünn gefärbt, bald geschlängelt, bald aufgequollen. Auch die Fibrillennetze zeigen verschiedene Degeneration, d. h. sie haben bald ihre normale Anordnung verloren, sind bald schmutzig tingiert oder sind ganz verschwunden. Diese Veränderungen der Fibrillennetze sind an den Ganglienzellen auffallend. Es haben sich dort Vakuolen gebildet, oder die Nisslschen Körperchen sind stark zersetzt.

2. Die weisse Substanz ist im Vergleich mit der grauen 